Article

\title{
Development and Cell Cycle Activity of the Root Apical Meristem in the Fern Ceratopteris richardii
}

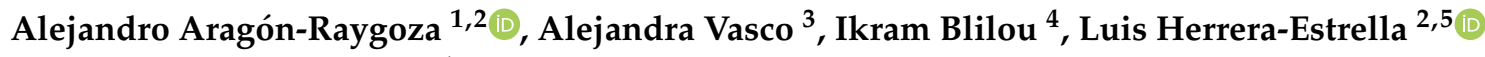 \\ and Alfredo Cruz-Ramírez ${ }^{1, *}$ \\ 1 Molecular and Developmental Complexity Group at Unidad de Genómica Avanzada, Laboratorio Nacional \\ de Genómica para la Biodiversidad, Cinvestav Sede Irapuato, Km. 9.6 Libramiento Norte Carretera, \\ Irapuato-León, Irapuato 36821, Guanajuato, Mexico; aragon.alejandro89@gmail.com \\ 2 Metabolic Engineering Group, Unidad de Genómica Avanzada, Laboratorio Nacional de Genómica para la \\ Biodiversidad, Cinvestav Sede Irapuato, Km. 9.6 Libramiento Norte Carretera, Irapuato-León, \\ Irapuato 36821, Guanajuato, Mexico; lherrerae@cinvestav.mx \\ 3 Botanical Research Institute of Texas (BRIT), Fort Worth, TX 76107-3400, USA; avascog@gmail.com \\ 4 Laboratory of Plant Cell and Developmental Biology, Division of Biological and Environmental Sciences and \\ Engineering (BESE), King Abdullah University of Science and Technology (KAUST), \\ Thuwal 23955-6900, Saudi Arabia; ikram.blilou@kaust.edu.sa \\ 5 Institute of Genomics for Crop Abiotic Stress Tolerance, Department of Plant and Soil Science, \\ Texas Tech University, Lubbock, TX 79409, USA \\ * Correspondence: alfredo.cruz@cinvestav.mx
}

Received: 27 October 2020; Accepted: 26 November 2020; Published: 4 December 2020

check for updates

\begin{abstract}
Ferns are a representative clade in plant evolution although underestimated in the genomic era. Ceratopteris richardii is an emergent model for developmental processes in ferns, yet a complete scheme of the different growth stages is necessary. Here, we present a developmental analysis, at the tissue and cellular levels, of the first shoot-borne root of Ceratopteris. We followed early stages and emergence of the root meristem in sporelings. While assessing root growth, the first shoot-borne root ceases its elongation between the emergence of the fifth and sixth roots, suggesting Ceratopteris roots follow a determinate developmental program. We report cell division frequencies in the stem cell niche after detecting labeled nuclei in the root apical cell (RAC) and derivatives after $8 \mathrm{~h}$ of exposure. These results demonstrate the RAC has a continuous mitotic activity during root development. Detection of cell cycle activity in the RAC at early times suggests this cell acts as a non-quiescent organizing center. Overall, our results provide a framework to study root function and development in ferns and to better understand the evolutionary history of this organ.
\end{abstract}

Keywords: plant development; embryogenesis Ceratopteris; determinate growth; root meristem; apical cell; merophytes; cell division

\section{Introduction}

Exploring the diversity of plant lineages using evo-devo approaches provides insights of how different organs and certain innovations that integrate the sporophyte plant body emerged during the evolution of embryophytes [1] (Figure 1A). Delving into root evolution, several studies suggest that convergent evolutionary events took place in both extant tracheophyte lineages: lycophytes and euphyllophytes (ferns and seed plants; Figure 1A, blue circles). The evolution of roots in lycophytes occurred in a stepwise manner, where gradual stages were found in the fossil record [2-5]. Root evolution in lycophytes is considered the first appearance of this organ in vascular plants, followed by a second evolutionary event which likely occurred in the ancestor of euphyllophytes [6] (Figure 1A). 
Ferns are the sister group of seed plants and therefore a key lineage to understand the evolution and development of the plant body in tracheophytes [7]. Ceratopteris richardii (Ceratopteris) is a subtropical fern in the Pteridaceae family, which has been considered "the Arabidopsis of the fern world". This fern presents certain advantages: easiness to culture in laboratory; short life cycle; genetic transformation techniques; and a draft genome sequence [8-13]. Ceratopteris is becoming a more approachable plant model to study developmental biology in ferns. Therefore, an accurate and complete characterization of its ontogenesis is necessary to pursue further research with this organism. Recently, a description summarizing several developmental stages in Ceratopteris was generated [14]. However, a detailed description of the early sporophyte development, immediately after gametophyte fertilization, and root emergence has not been accomplished yet.

Ceratopteris establishes an homorhizic root system where no primary root is developed but the continuous emergence of shoot-borne roots. Ceratopteris not only generates stem-borne roots (SBRs), but also leaf-borne roots [40]. SBRs develop from a direct derivative (merophyte) of the shoot apical cell. This derivative will be a progenitor cell for a leaf and a SBR. Leaf-borne roots emerge at the base of each leaf, and more than one root can develop [40]. Some aspects of Ceratopteris root system have been previously characterized, moreover there are several elements from the emergence and development of this organ that need to be determined in order to establish Ceratopteris SBR as a model for developmental biology and evo-devo approaches.

As an organ with active growth, a root bears an apical meristem with stem cells that are mitotically active, to self-renew, and generate specific daughters for diverse cell layers [19,41]. The development and arrangement of apical meristems in ferns is one of the most peculiar traits in this lineage. Several fern species display a root apical meristem with a prominent tetrahedral apical cell in the promeristem or stem cell niche [42] (Figure 1B; Table S1). This single apical cell generates all the different cell layers that conform the root body $[25,40]$. This is a major difference with the Arabidopsis root stem cell niche (RSCN), where specific initials generate each of the diverse cell layers [43]. A similar RSCN to that of Ceratopteris is present in several species of the lycophyte order Selaginellales (Figure 1B). This organization is not present in other lycophytes, since other types of RAM arrangement have been described in the orders Isoëtales and Lycopodiales [2,29] (Figure 1B).

In the present work, we performed a developmental analysis of the first stem-borne root of Ceratopteris, at organ, tissue, and cellular levels. We followed the early stages of the embryo and the root meristem establishment after gametophyte fertilization. We detected the diverse set of cell layers that compose Ceratopteris root body by tracking layer-specific traits, such as Casparian strip in endodermis and lignin accumulation in xylem. We analyzed the cell division frequency in the root apical cell and its derivatives at the RSCN after exposure to EdU at different times, and observed a high frequency of labeled S-phase cells after $8 \mathrm{~h}$ of exposure, suggesting that the entire Ceratopteris RAM has an active cell cycle until it enters a determinate program leading to root growth cessation. Our results point out that the root apical cell in Ceratopteris regularly divides which support the hypothesis of this cell high mitotic rate, a disputed fact in ferns development, and propose the absence of a quiescent center in Ceratopteris RSCN. 
A

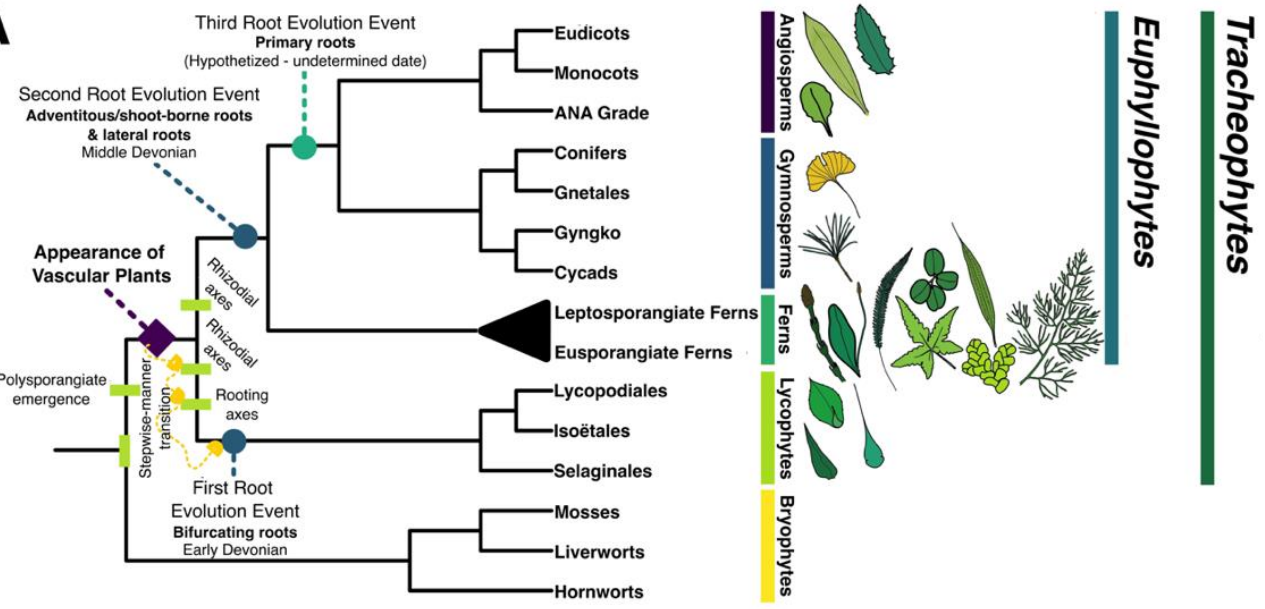

B

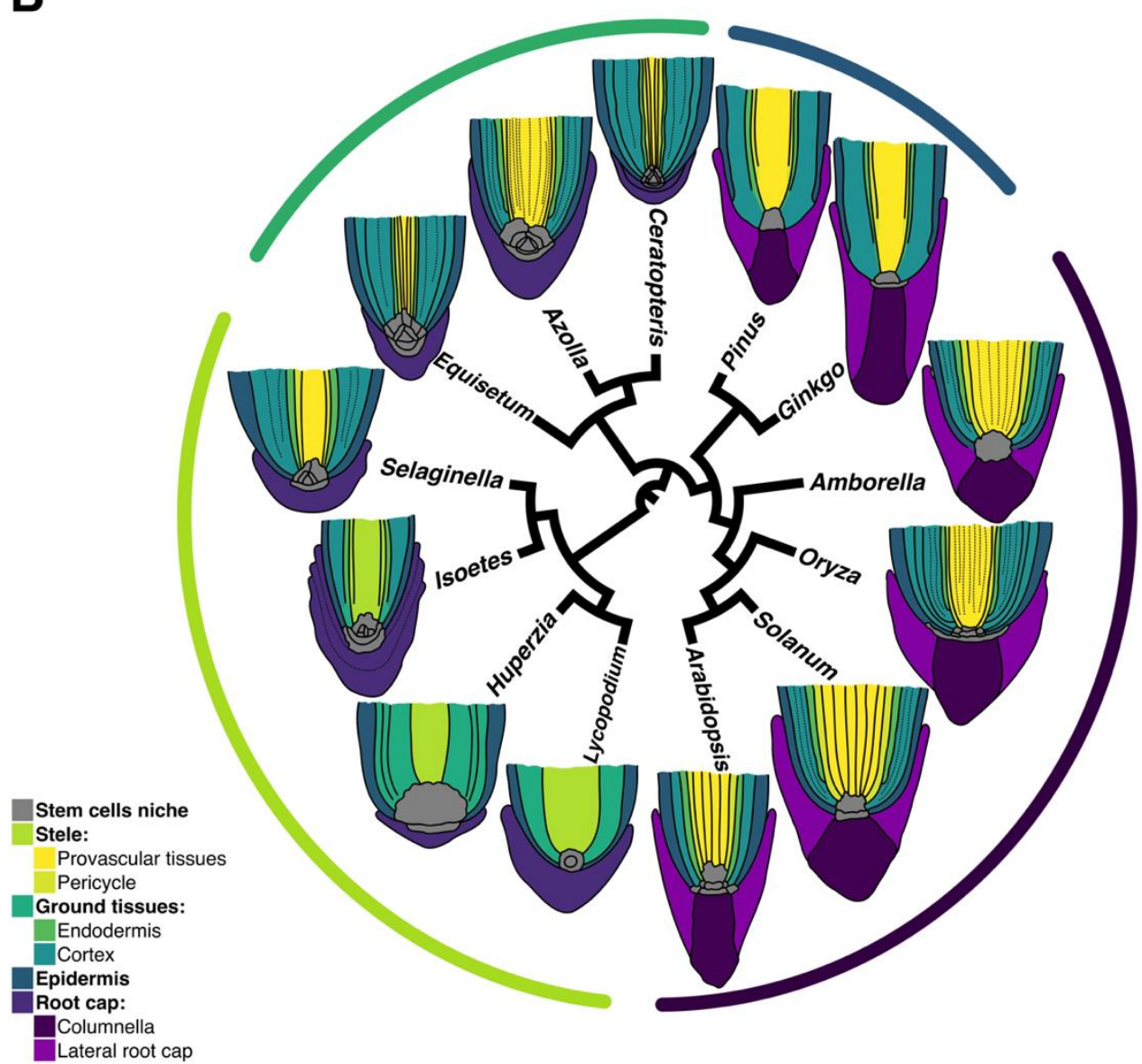

Figure 1. Evolution among major vascular plant lineages and its relation to root meristem organization. (A) Hypothesis of root evolution in vascular plants. Both major extant vascular plant lineages, lycophytes and euphyllophytes, have been hypothesized to independently evolve roots. Based on [3,4,6,15-18]. (B) Schematic representation of cell layer organization and stem cell niches in different described roots from extant vascular plants (Table S1). Meristem diversity has been extensively assessed across flowering plants, but not in other lineages. Color lines covering the roots, correspond to color patterns represented in A. The different RAM morphologies showed in Figure 1B were obtained from published articles. The scientific name of each species, its plant lineage and the corresponding reference can be found in Table S1 in Supplementary Materials. [19-39]. 


\section{Materials and Methods}

\subsection{Plant Growth and Culture Conditions}

Ceratopteris Hn-n spores were cultured in C-Fern Medium (CFM, 0.5 g/L MES, pH 6.0, 0.8\% agar) at $25{ }^{\circ} \mathrm{C}$ with a photoperiod of $16 \mathrm{~h} / 8 \mathrm{~h}$ light/dark. Spores were sterilized prior to culture [9] and synchronized in darkness for three days. When gametophytes were found sexually competent (15 days post sowing [dps]), water was added to the culture for the fertilization to take place. In the following experiments, 30 daf (45 dps) sporelings (expanded first leaf and visible first root) were cultured in CFM plus $2 \%$ sucrose at the same conditions.

While previous works stated $28^{\circ} \mathrm{C}$ as the optimal growth temperature, Ceratopteris can also grow from 21 to $30^{\circ} \mathrm{C}$. Ceratopteris development would increase up to twice at $21-22{ }^{\circ} \mathrm{C}$ compared to optimal temperature $[9,44]$. An extended duration of Ceratopteris development was observed in our results because of the growing temperature used in this work $\left(25^{\circ} \mathrm{C}\right)$. However, no morphological change was observed when compared with previous reports.

\subsection{Fixation and Clearing}

Gametophytes and sporophytes were fixed immediately after collection in $4 \%$ p-formaldehyde and $0.1 \%$ Triton X-100 in PBS 1X for 30 min and vacuum was applied. Following, tissues were washed using PBS 1X. All tissues were cleared in the ClearSee solution for at least one week. ClearSee was changed in sporophyte tissues every three days. We used the ClearSee technique since it allows the visualization of the whole plant [45].

\subsection{Tissue Sections and Staining}

Plant sporelings were embedded in $4 \%$ agarose and hand-sectioned using razor blades. For transversal staining, $1 \mu \mathrm{g} / \mathrm{mL}$ Calcofluor White (or Fluorescent Brightener 28 [Sigma-F3543] was applied to agarose sections for one hour prior the observation [46]. For Casparian strip detection, fresh root sections were treated as [43]. For differential layer detection, fresh root sections were treated with a modified version as [47]; agarose sections were incubated in lactic acid for one hour, then transferred to berberine hemisulfate solution ( $0.1 \%$ in lactic acid) and incubated for $90 \mathrm{~min}$ at room temperature. Sections were washed with water until they were cleared and then incubated in $0.5 \%$ safranin $\mathrm{O}$ (in $50 \%$ ethanol) less than a minute. Finally, sections were washed with water until cleared. All slides were mounted in 50\% glycerol.

For observation of amyloplasts, whole roots were cleared in ClearSee [45] and then stained in lugol solution. Additionally, Ceratopteris sporelings were stained with $1 \mu \mathrm{g} / \mathrm{mL}$ Calcofluor White $(\mathrm{CW})$ and $20 \mu \mathrm{g} / \mathrm{mL}$ Propidium Iodide (PI), to observe cell wall and nuclei, respectively. Both dyes were applied in ClearSee. First, CW for $1 \mathrm{~h}$, then wash in ClearSee for $30 \mathrm{~min}$. Second, PI for $30 \mathrm{~min}$ and then wash in ClearSee for $30 \mathrm{~min}$. Finally, samples were mounted in 50\% glycerol. This treatment was also applied for gametophytes.

\subsection{Meristem Cell Size and Root Growth Analysis}

Ceratopteris sporelings of 30 daf were grown in CFM plus 2\% Sucrose for four days and plants were sampled at different times: 8 and $12 \mathrm{~h}$, and 1 to 4 days. They were fixed and cleared as previously described. Plants were stained in Calcofluor White at $1 \mu \mathrm{g} / \mathrm{mL}$ dissolved in ClearSee solution for $15 \mathrm{~min}$ and then washed in ClearSee solution for at least one hour. Samples were observed in CLSM. Outer cortex cells in the root meristem were counted for both sides in each plant and then the mean was calculated for at least 30 different plants. We conducted a paired Student's $t$ test to assess statistical differences of the number of cortical cells in the root meristem.

Sporelings of 30 daf were transferred to CFM plus $2 \%$ sucrose and $0.4 \%$ Gellan Gum (G434-PhytoTech Labs, Lenexa, KS, USA) and placed vertically in a growth chamber at the same aforementioned conditions. Two media plate changes were applied to each original plate (once each 
fifteen days). Each sporeling was handled carefully during change of media plate, assuring that roots were in contact with the solid medium. To avoid undesired effects due to contamination, nutrient limitations, agar dehydration and space constraints, we carefully changed sporelings to fresh growth medium every ten days. Root growth was registered every five days in each visible root or organ primordia observed for 30 days. We monitored the development of the earliest seven SBRs (SBR1-7), until extra root primordia appeared at the base of the seventh leaf (leaf-borne roots). The sample was composed of 30 sporelings and for subsequent analysis we randomly selected 20 of these sporelings. Statistical differences between the length of different SBRs and different times were assessed using a paired student's $t$ test, while root growth rate was approached by using one-way ANOVA.

\subsection{EdU Incorporation Treatment}

For the EdU incorporation, 30 daf sporelings were cultivated in CFM plus $2 \%$ sucrose and $4 \mathrm{mM}$ EdU plates. Sporelings were collected and fixed as previously mentioned at different times $(8$ and $12 \mathrm{~h}$, $1,2,3,4$ and 5 days) after culture. Sporelings were cleared in ClearSee for one week, stained in CW for $1 \mathrm{~h}$, washed in PBS 1X two times for $10 \mathrm{~min}$, then the Click-iT EdU staining kit (C10337, Invitrogen, Carlsbad, CA, USA) was used for signal development, washed in PBS 1X two times for $10 \mathrm{~min}$ and stained in PI for $30 \mathrm{~min}$, washed in ClearSee for $30 \mathrm{~min}$ and mounted in $50 \%$ glycerol, prior their observation $[48,49]$. The frequency of cells in S-phase was calculated with the number of nuclei incorporating EdU (Alexa488 signal) divided by the total number of nuclei in the analyzed region (PI signal). Statistical differences between incorporation times and zones were assessed using a pairwise student's $t$ test.

\subsection{Microscopy and Image Analysis}

Confocal laser scanning microscopy (CLSM) images of both gametophytes, sporelings, and root sections were performed on a Zeiss LSM800 microscope. The different dyes used were excited and detected as follows: calcofluor white, ex: $405 \mathrm{~nm}$ laser, dt: SP 470 filter band; Alexa488, ex. $488 \mathrm{~nm}$ laser, dt. SP 545 filter band; propidium iodide, ex. $561 \mathrm{~nm}$ laser, dt. LP 575 filter band; berberine hemisulfate and aniline blue, ex. $488 \mathrm{~nm}$ laser, dt. SP 545 filter band. All lasers were used at 15\% intensity and detected using 1 pinhole unit. Differential interface contrast microscopy was used to take whole-mount roots stained with lugol and other root sections, on a Leica DM6000B microscope. Using this microscope, sections stained with berberine hemisulfate and safranin were subjected to fluorescence light and images detected while using a GFP filter. The gametophyte-to-sporophyte development images were taken on a stereo microscope Leica EZ4-FD. Images were organized using Inkscape 0.92.4. Line art figures were designed using Inkscape 0.92.4 and colored with GIMP 2.10.12.

\section{Results}

\subsection{Establishment of the First Root during Embryonic Development in Ceratopteris Sporophyte}

We explored the early stages of Ceratopteris sporophyte to understand the embryo development and to track the emergence of the first root. While this work was in progress, the different stages of Ceratopteris development were described by Conway and Di Stilio [14]. We not only covered similar stages to those reported, but also expanded the developmental phases of the early sporophytes during zygote formation and embryo development (Figure S1A).

Our results showed that both gametophytes reach their sexual maturity at 15 days post sowing (dps) at $25^{\circ} \mathrm{C}$ (Figure S1A,B). Male gametophytes are filled with antheridia and circularized sperms are observed inside them (Figure 2A and Figure S1A). Hermaphrodite gametophytes develop both antheridia and archegonia. Archegonia develop below the notch meristem, and an egg cell develops within each archegonium (Figure 2B,C and Figure S1B). Mobile sperms are able to reach the archegonium tip to fertilize the single egg cell (Figure 2D and Figure S1C). Following fertilization, the zygote forms and then embryo development proceeds (Figure 2E-M). 

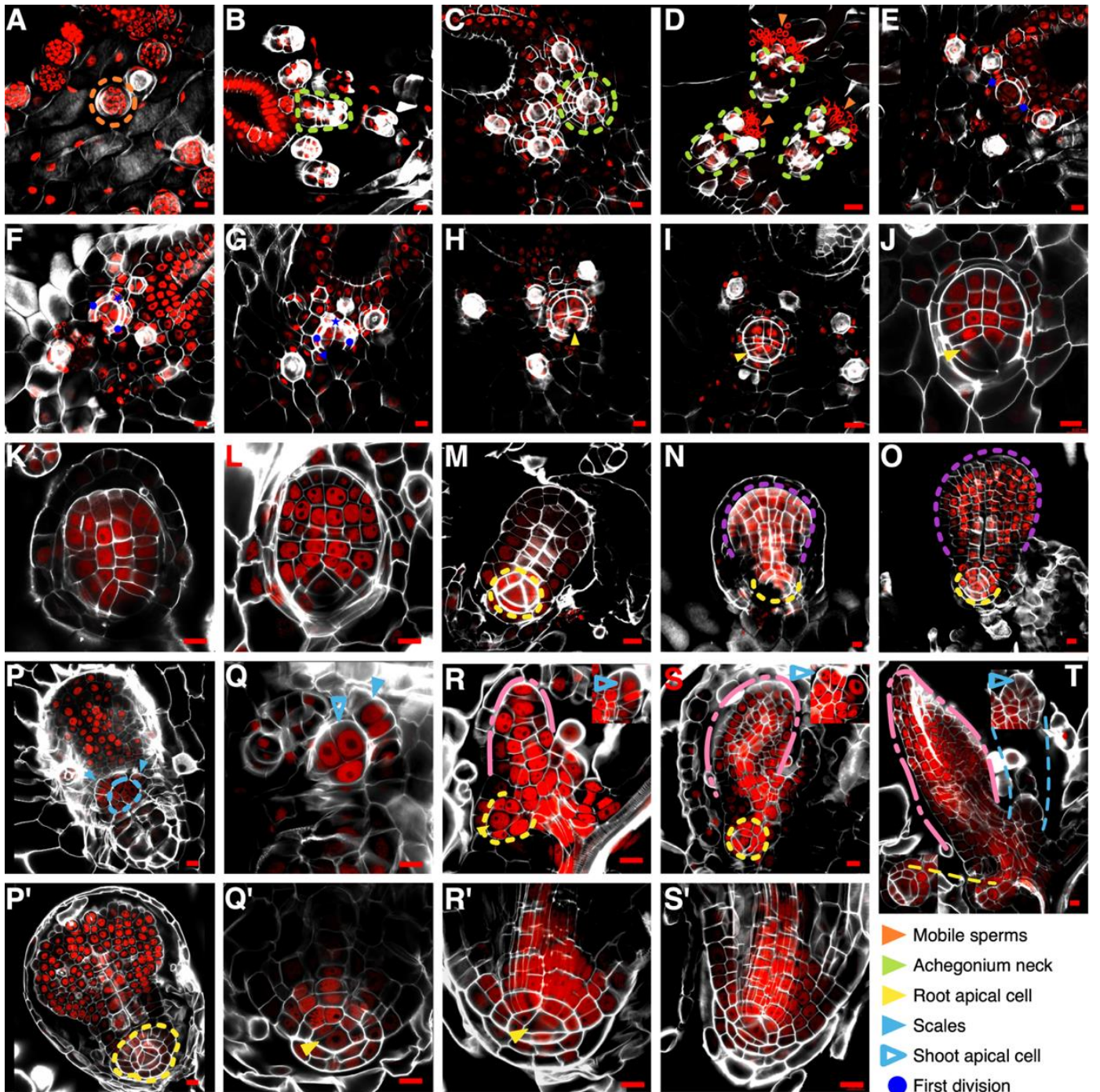

$\ldots$ Anteridium

$\ldots$ Cotyledon / first leaf
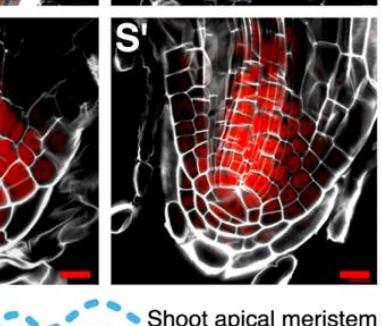

Mobile sperms

Achegonium neck

Root apical cell

$>$ Scales
$>$ Shoot apical cell

First division

$0^{\circ}$ Archegonium $=0^{\circ}$ Root primordium

Second leaf

\section{Epi-outer division}

$\triangle$ Hypo-outer division

Figure 2. CLSM images of gametophyte-to-sporophyte transition and embryo development in Ceratopteris richardii. (A) Antheridia in a male gametophyte at $15 \mathrm{dps}$. (B,C) Archegonia in a hemaphrodite gametophyte at $15 \mathrm{dps}$. (D) Archegonial necks are reached by mobile sperms. (E-G) Early developmental stages of the embryo: two-celled embryo (E); epibasal division in an octant embryo (F); hypobasal division in an octant embryo $(\mathbf{G})$. $(\mathbf{H}-\mathbf{O})$ The RAC is specified early in embryo development and a root primordium begins to form. Additionally, the first leaf grows until breaking the calyptra. (P-T; $\left.\mathbf{P}^{\prime}-\mathbf{S}^{\prime}\right)$. Other components are also developing: shoot apical meristem (P,Q); first root primordium with a root cap $\left(\mathbf{P}^{\prime}, \mathbf{Q}^{\prime}\right)$. Sporophytes continue to develop and new organs emerge $(\mathbf{R}-\mathbf{T})$. Additionally, the first SBR begins to grow and the whole root body develops; all cell layers recognizable $\left(\mathbf{R}^{\prime}, \mathbf{S}^{\prime}\right)$. Scale bars: $20 \mu \mathrm{m}$. White-Calcofluor White; Red-Propidium Iodide.

Between 1 to 3 days after fertilization (daf; Figure S1D-F), the embryo is detected between its two-celled and octant stages (Figure 2E-G). The first division (Figure 2E, blue dots) occurs perpendicular to the anterior-posterior axis of the gametophytes (Figure S2), forming the epibasal (anterior) and hypobasal (posterior) cells. The subsequent division generates an embryo in a quadrant stage, but this division occurs in a vertically median plane and we were not able to observe it. We detected divisions in the outer cells of the quadrant embryo: first, a symmetric division occurs at the epibasal outer quadrant (Figure 2F, blue star), and later an asymmetric division takes place at the hypobasal outer quadrant 
cell (Figure 2G, blue triangle). The hypobasal outer octants displayed an observable asymmetry, from these octants the first root would emerge (Figure 2G, blue triangle).

At 3 daf, the embryo is recognizable as a swelling lump in the fertilized archegonium (Figure 2F,G-J, purple arrowhead), but keeps developing inside the gametophyte, covered by a calyptra. Parallel in time, a prominent tetrahedral-shaped cell can be distinguished at the distal part of the embryo (Figure 2H-J; yellow arrowhead). Because of its position and consistent presence in latter stages (Figure 2K-O), it is likely that this cell is the first root apical cell (RAC). From 4 to 7 daf, the first leaf grows and expands, acquiring a rounded shape (Figure 2N,O; purple line; Figure S1G-J) and a complete root primordium develops (Figure 2N,O; yellow line), but the growth of each organ occurs at a different rate.

The calyptra breaks around 8-9 daf because of the growing first leaf (Figure S1K,N). The first leaf reaches a wide spatula shape (Figure S1N,O, purple line \& blue arrowhead). Around 15 daf, the first SBR begins to grow and a prominent root tip can be clearly observed (Figure S1N, yellow line). All root cell layers can be distinguished after 20 daf (Figure S1O, yellow line). At the same time, the second leaf (Figure 2R-T, pink line; S1O) and a new root primordium appear, and again the growth rate of the root seems to be delayed compared with that of the leaf (Figure 2R-T, yellow line). While the first SBR keeps developing, the different layers forming the root body, including the root cap, are detected in longitudinal planes (Figure $2 \mathrm{P}^{\prime}-\mathrm{S}^{\prime}$, blue-filled arrowheads; Figure S3).

The first leaf and the embryonic root developed at a dorsal plane in relation to the gametophyte, the shoot apical meristem (SAM) develops at the ventral plane (Figure 2P, blue line). The SAM is surrounded by scales (Figure 2P, blue-filled arrowheads) and the shoot apical cell (SAC) is distinguishable, due to its inverted tetrahedral shape with a rounded distal face (Figure $2 \mathrm{P}, \mathrm{R}-\mathrm{T}$, insets). Based on observation of multiple events, we summarized Ceratopteris development using a graphic representation from the spore to young sporophytes (or sporelings), with a main focus on the first root specification and development (Figure 3).

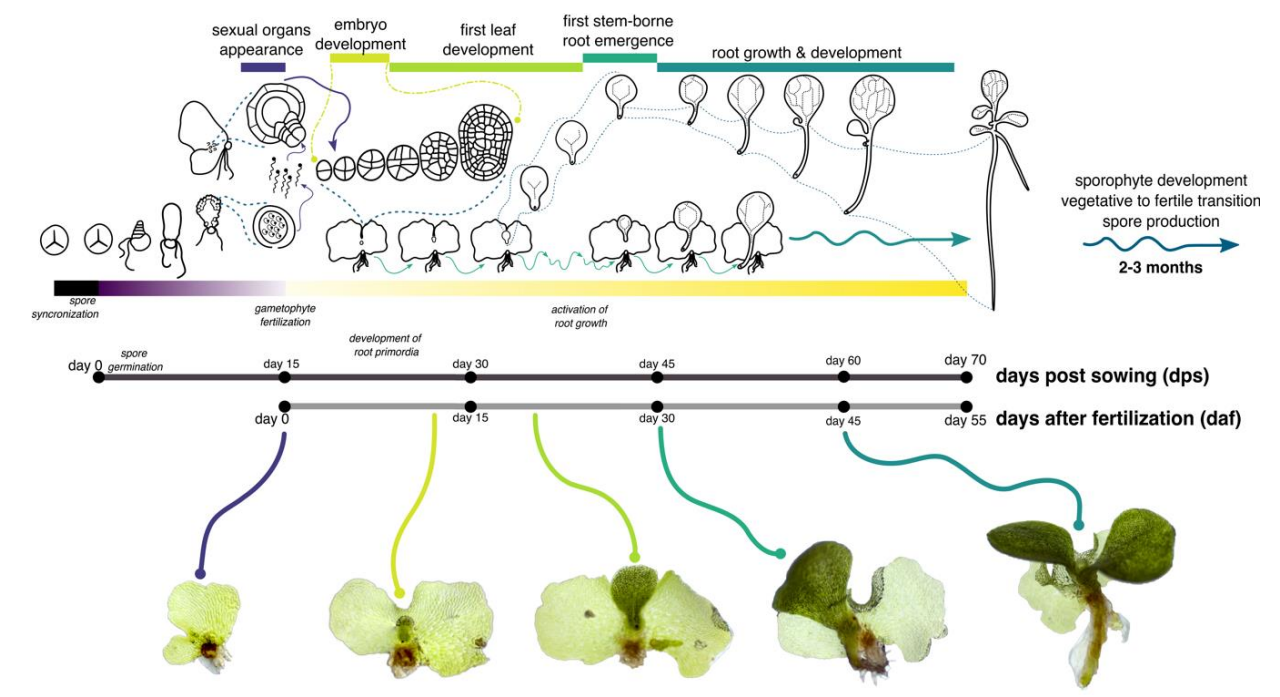

Figure 3. Graphic summary of Ceratopteris richardii development from a spore to the young sporophyte, with a focus on the first stem-borne root emergence and development. At the bottom, major developmental stages can be observed: (from left to right) a sexually-mature hermaphrodite gametophyte; a 6-daf sporophyte; a 10-daf sporophyte; a 30-daf sporophyte with a visible SBR-1; a 45-daf sporophyte with several leaves and a growing SBR-1. A complete diagram of the day by day development of Ceratopteris sporophyte can be found in Figure S1.

\subsection{Zonation of the First Shoot-Borne Root}

Roots can be divided in three different zones: meristematic (MZ); elongation (EZ); and differentiation zones (DZ). The MZ is located at the distal part of the root where cells are actively dividing with a high mitotic rate. Zonation can be established by measuring the meristem 
size based on the number of cortical cells from the stem cell niche to the last cortex cell without any signs of elongation. We used the same method to determine the different zones of the Ceratopteris root. We detected the outer cortical layer in roots of 30 daf sporelings (Figure 2A,D and Figure 4A,B). We decided to use Ceratopteris sporelings at 30 daf in our following experiments since these plants have a well expanded first leaf and the first root is beginning to grow (Figure S1P). Changes in cell length and width are easy to detect in the outer cortex, because this layer does not display any other evident changes during differentiation (Figure 4B, dotted line).
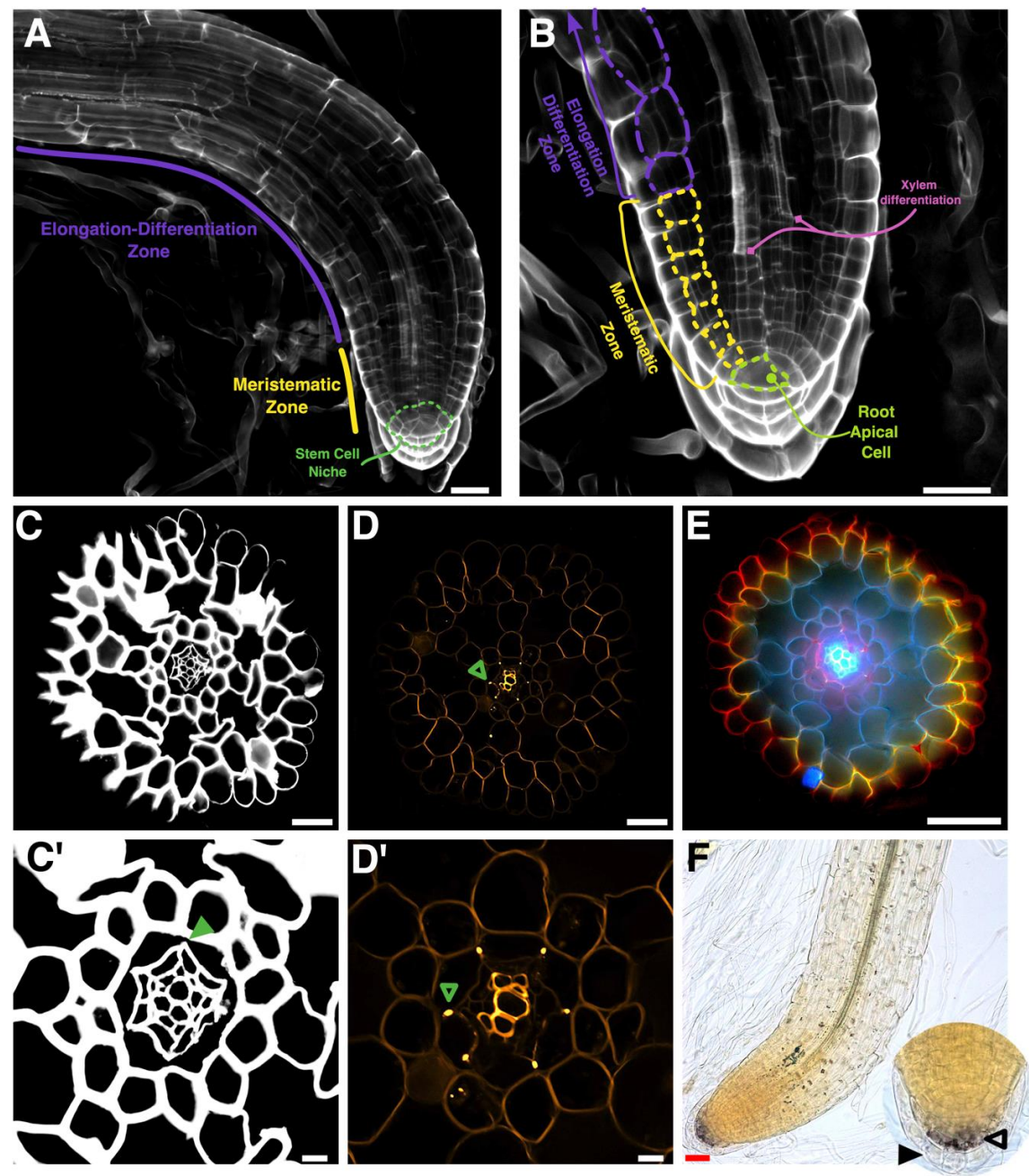

Figure 4. Histological analyses of the Ceratopteris richardii first stem-borne root. (A) Whole root stained with Calcofluor White with the established zonation. (B) The RAM in 30 daf Ceratopteris sporelings has a prominent tetrahedral apical cell. The cell length changes between MZ and EDZ after the meristem boundary. The meristematic zone ends when cells begin to elongate. The change in cell elongation can be detected by measuring length of the outer cortex layer. The xylem cells begin to differentiate before leaving the meristematic zone. The Ceratopteris first stem-borne root meristem has an average size of is seven cells. $\left(\mathbf{C}, \mathbf{C}^{\prime}\right)$ Transverse section of a root, stained with Calcofluor White to detect cell walls and observed with CLSM. Endodermal cell walls did not stain (green arrowhead). $\left(\mathbf{D}, \mathbf{D}^{\prime}\right)$ Transverse section of a root stained with berberine and aniline blue. Vasculature and endodermis positions were assigned due to the fluorescent signals in the xylem cell walls and the Casparian strip, respectively (green unfilled arrowhead). (E) Transverse section of a root stained with berberine, lactic acid, and safranin, observed in an epifluorescence microscope. (F) Amyloplasts detection using lugol staining in the root. (Inset) A strong signal is detected in the middle layer of the root cap (black-empty arrowhead) but not in the outer layer (black-filled arrowhead). Scale bar: $50 \mu \mathrm{m}(\mathbf{A}-\mathbf{F}) ; 10 \mu \mathrm{m}\left(\mathbf{C}^{\prime}, \mathbf{D}^{\prime}\right)$. 
Cells within the MZ have a similar length and width, while those in the elongation and differentiation zone (EDZ) have extended their length (Table 1A, Figure 4B). We established the probable meristematic boundary in each root based on discernible cell changes and measured the length of three different cells in each direction, rootward and shootward (Figure 4B). We found a distinctive change in cell length among cells inside and outside the MZ boundary (Table 1A), where a rapid elongation occurs after cells move away from the meristem. We also assessed cell width, but no considerable change was detected in both zones (Table 1A). However, there is a large standard deviation in EDZ length due to a rapid elongation change between these cells (Table 1A; Figure 4B; wide-dotted line).

Table 1. Root zonation and meristem size determination of the first stem-borne root of Ceratopteris richardii. (A) The meristematic zone ends when cells begin to elongate. The change in cell elongation can be detected by measuring length of the outer cortex layer. Both measurements were assessed by using a paired student's $t$ test. (B) The Ceratopteris first stem-borne root meristem size is seven cells in average at 30 daf.

\begin{tabular}{|c|c|c|c|c|c|c|c|c|c|}
\hline \multirow{3}{*}{ A } & \multicolumn{5}{|c|}{ Cell Size } & \multirow{5}{*}{ B } & \multirow{2}{*}{\multicolumn{3}{|c|}{ Cell Number }} \\
\hline & \multicolumn{2}{|c|}{ Length $(\mu \mathrm{m})$} & \multicolumn{2}{|c|}{ Width $(\mu \mathrm{m})$} & \multirow{2}{*}{$\mathbf{n}$} & & & & \\
\hline & Mean & SD (+/-) & Mean & SD (+/-) & & & Mean & SD (+/-) & n \\
\hline $\begin{array}{l}\text { Meristematic } \\
\text { Zone }\end{array}$ & 16.32 & 2.42 & 18.36 & 2.28 & \multirow{2}{*}{20} & & \multirow{2}{*}{7.00} & \multirow{2}{*}{1.34} & \multirow[b]{2}{*}{50} \\
\hline $\begin{array}{c}\text { Elongation/Differentiation } \\
\text { Zone }\end{array}$ & 36.79 & 12.09 & 25.22 & 3.62 & & & & & \\
\hline
\end{tabular}

After identifying the meristem boundary, based on the number of outer cortex cells, we determined the meristem size, from one-celled merophyte till the last cortical cell at the MZ border. Merophytes were considered because they behave as initial cells and generate all different proximal tissues, including the outer cortex (Figure S3). We found that the MZ in Ceratopteris first SBR has a median size of 7 cells (SD +/- 1.34; Table 1B). Based on these results, the first SBR is composed by a narrow root cap that covers the promeristem or RSCN (Figure 4A), which is inside a short MZ that includes the RAC, merophytes (pluripotent derivatives) and transit-amplifying cells (Figure S3). Ceratopteris meristem size may change because of the root growth dynamics or the effect of diverse stimuli. Our results could be used in further research as standardized measures in Ceratopteris first SBR with an active meristem, since they may be helpful for subsequent analyses in this fern.

\subsection{Histochemical Identification of the Different Root Cell Layers}

After longitudinal zones were established, we analyzed the radial arrangement and identity of specific traits within the defined concentric layers of Ceratopteris roots. We obtained transversal sections from the elongation-differentiation root zone (EDZ) of 30 daf sporelings. First, we used calcofluor white $(\mathrm{CW})$ to observe the whole radial morphology of Ceratopteris root (Figure $4 \mathrm{C}, \mathrm{C}^{\prime}$ ). We identified six cell layers organized in uninterrupted concentric circles and the central cylinder (Figure 4C). Based on cellular morphology, and a previous report, the central cylinder contains the vascular tissues (xylem and phloem) with the next two layers probably corresponding to the pericycle and the endodermis. (Figure $4 C^{\prime}$ ). Subsequently, we performed berberine and aniline blue staining that allows dyeing lignin and suberin that accumulates in endodermis and xylem (Figure 4D, $\mathrm{D}^{\prime}$ ). We detected the Casparian strip (CS) as highly fluorescent dots between cell walls of the fifth cell layer, showing that this layer corresponds to the endodermis (Figure $4 \mathrm{D}^{\mathrm{D}} \mathrm{D}^{\prime}$, green empty arrowhead). In CW-stained roots, there is no staining of the CS because of the larger accumulation of lignin and suberin, replacing the typical polymers in cell walls which $\mathrm{CW}$ is able to bind (Figure $4 \mathrm{C}^{\prime}$; green filled arrowhead). We also detected a fluorescent signal in the central cylinder, which may correspond to xylem cells due to their strong lignification and their anatomical characteristics (Figure $4 \mathrm{D}^{\prime}$ ).

A previous report showed that the staining of epidermis and exodermis in onion roots after being treated with berberine and safranin. We choose this procedure to discern the root epidermis and to 
demonstrate whether an exodermis was present in Ceratopteris roots. We obtained a remarkable staining pattern, since the major cell layers were stained in different colors (Figure 4E). Vascular tissues are detected in a bright blue color, pericycle in pink, endodermis in purple with intense Casparian strip fluorescing dots (Figure 4E). The middle cortex and cortical aerenchyma are dark blue, whereas the outer cortex displays a color gradient, from dark blue (inner cell wall) to yellow (outer cell wall). Finally, the epidermis is stained in bright red (Figure 4E). No sign of an exodermis layer adjacent to the epidermis was found. This result presented a differential color pattern to distinguish between all root cell layers.

A well-known trait of the differentiated root cap layers (RC), in other species, is the presence of amyloplasts. Therefore, we tested if these types of plastids were present in Ceratopteris RC by using lugol staining (Figure 4F). We observed amyloplasts in the RC cells but also in other cells in the root body at the EDZ. Amyloplasts were observed after the RCI, where root cap cells differentiate (Figure 4F; inset, empty black arrowhead). On the other hand, the last RC layer lacks any stain trace, suggesting that amyloplasts are lost in these cells and/or represents another stage of this layer (Figure 4F; inset filled black arrowhead). Overall, these histological techniques allowed us to distinguish the different cell layers present in the Ceratopteris root: the stem cell niche with the prominent tetrahedral RAC; the amount of lignin in xylem cells depending on their stage; the CS in endodermis; a middle cortex that generates aerenchyma, since Ceratopteris is a semiaquatic plant; the outer radial layers; and different amount of amyloplasts in the protective root cap as a possible marker for differentiation. All these new data can be used in future studies to assess the functional characterization of genes that specify each cell lineage.

\subsection{Growth Analysis of Ceratopteris Stem-Borne Roots in Sporelings}

Since we were able to measure the cell number at the meristem of the first stem-borne root of Ceratopteris, we decide to analyze if this cell number was stable or displayed changes through time. As we established previously, we counted the number of cells in the outer cortex layer in Ceratopteris first SBR while examining this root at different time points (Figure 5A). Not detectable change in the number of cells was observed at $8 \mathrm{~h}$ of growing. After that observation, we began detecting an increase of a single cell after $12 \mathrm{~h}$ in cell number and another cell at $24 \mathrm{~h}$. This was the higher gain of two cells in the root meristem. Subsequent increase of the meristem size was detected until 4 days of growing (the last time analyzed). These results suggest that the root meristem in the first SBR is increasing its cell number at a rate of at least a single cell per day. We do not discard that the root meristem would keep increasing its cell number and even that this could change depending on the SBR analyzed.

In order to characterize the growth dynamics of Ceratopteris SBRs, we follow root growth on sporelings. Although previous work has been pivotal to understand Ceratopteris root development, we decided to assess growth behavior of the first SBR with respect to the development of further SBRs. We followed the growth of SBRs after a primordium was noticeable at each node. We recorded root length at diverse time points, defined as days of growth (Figure 5B). SBR-1 primordium was present in all sporelings at the beginning of the experiment, but no root elongation was observed until 5 days of growth which could be due to a non-synchronous development. At 10 days of growth, SBR-1s of all sporelings showed noticeable growth, SBR-2s were not yet observed. SBR-1 elongation continued slowly for 25 days (Figure 5B; indigo column). SBR-1 growth rate (RGR) was different from that of the subsequent roots, each newly-emerged root showed faster growth (Table S2). SBR-1 displayed a growth rate of $0.17 \mathrm{~mm}$ per day from $0-5$ days of growth. SBR-2 grew approximately at $0.29 \mathrm{~mm} / \mathrm{day}$ in a similar 5-days window (10-15 days of growth; Figure 5B, horizontal lines, Table S2).

All roots showed a similar behavior in their growth rate pattern through time, initially growing at a slow rate, then increasing the rate continuously until reaching their fastest elongation rate, and finally decreasing their rate (Table S2). We detected that between SBR1-3 has a similar RGR at the beginning of their development, but the RGR actually does change in each of these analyzed roots with a higher RGR in a higher rank SBR (Table S2). SBR-1 highest GR (0.99 mm/day) was between 10-15 days, 
after that its GR started to decrease (Figure 5B; indigo-colored column). SBR-1 reached its maximum length at 25 days of growth, after which only a marginal growth rate was observed $(0.07 \mathrm{~mm} / \mathrm{day}$ at 30 days Table S2). Based on these results, we suggest that SBR-1 enters a determinate growth program after 25 days of growth.

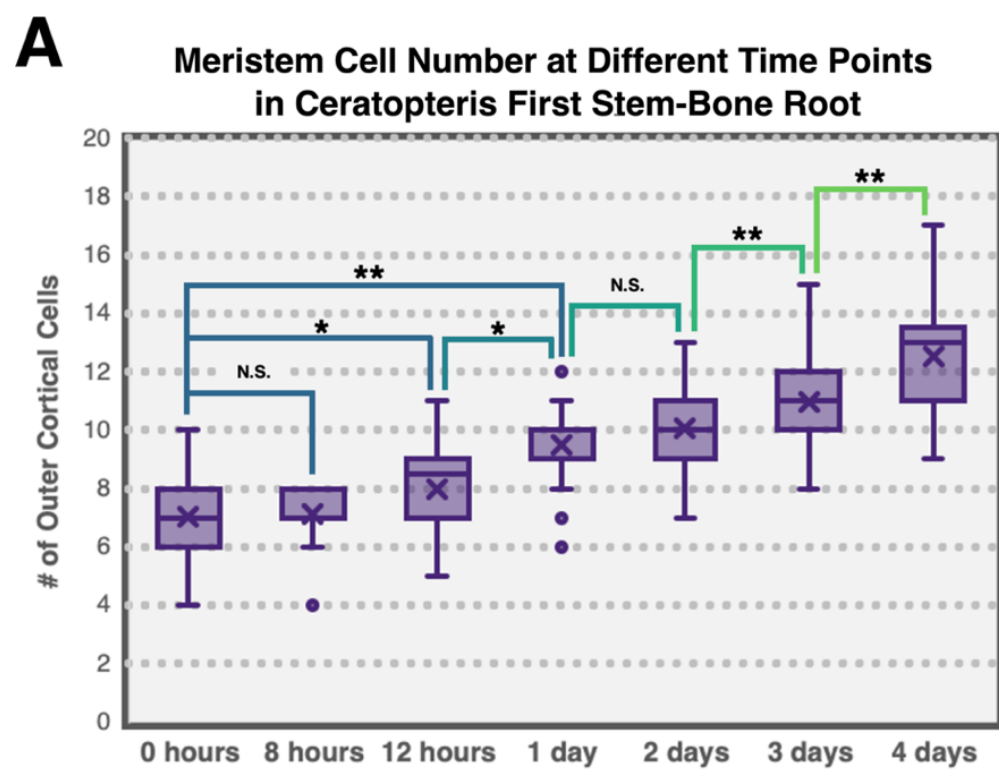

B Stem-Borne Roots in Ceratopteris Sporelings Time of Root Growth Experiment

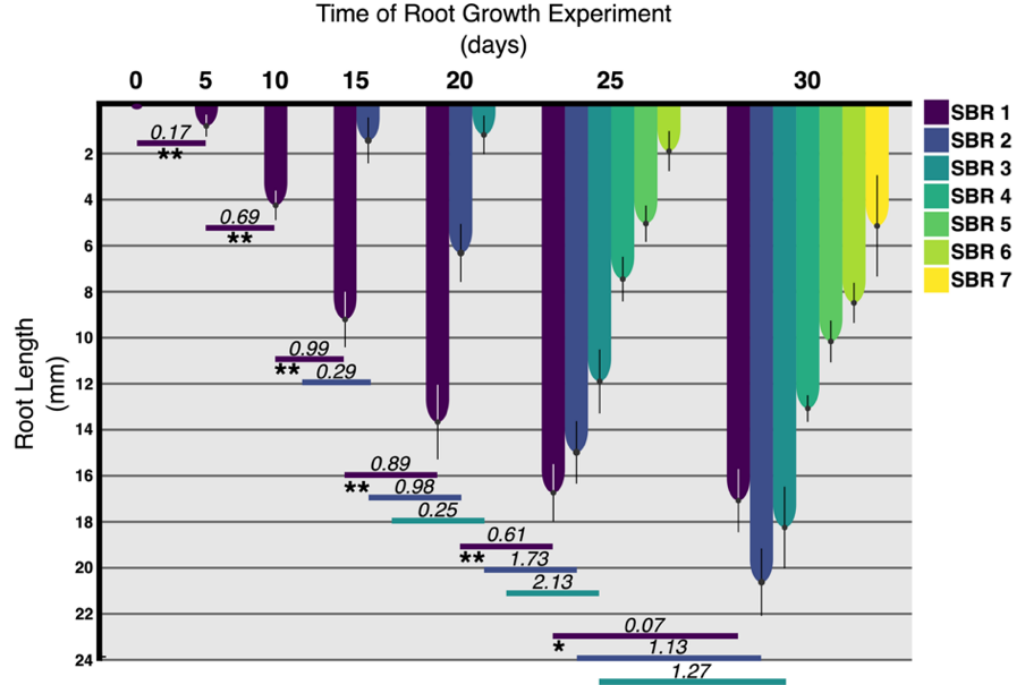

Figure 5. Root dynamics at the cell and organ level in Ceratopteris richardii. (A) Box plot of the analysis of the cell number in the first stem-borne root. A paired student's $t$ test was applied for number of cells in the meristem changing through time. (B) Growth analysis of the stem-borne roots. Column plot showing the growth analysis of stem-borne roots in Ceratopteris sporelings. Horizontal lines describe the growth rate of each SBR (according to color) in a timespan of 5 days. The statistical differences of root growth were assessed with a paired student's $t$ test. Standard deviation is displayed in each column. ${ }^{*} p<0.05 ;{ }^{* *} p<0.01$; NS-non significant.

\subsection{Cell Cycle Activity in the Root Apical Meristem}

The RAM of ferns has brought attention over several years, for the presence of the RAC and the precise segmentation patterns that occur in this organ. Nevertheless, two opposing hypotheses have existed: (1) the RAC acts as a quiescent center and rarely divides; and (2) the RAC frequently enters the cell cycle to divide. We determined cell cycle activity in the RAM by exposing Ceratopteris sporelings 
to 5-ethynyl-2'-deoxyuridine (EdU), after the SBR-1 began an active growth. Sporelings were collected at different times of EdU exposure to evaluate cell division activity. We divided Ceratopteris RSCN based on distinctive cell fates and/or developmental stages that could influence cell cycle activity (Figure 6G): the RAC (indigo-colored cell); merophytes or proximal initials (dark green-colored cells), direct daughters of the RAC involved in formative divisions; proximal cells (light green-colored cells), derived directly from merophytes; root cap initial or RCI (blue-colored cells), distal derivative of the RAC; and root cap cells (yellow-colored cells), distal cells entering a differentiation process.

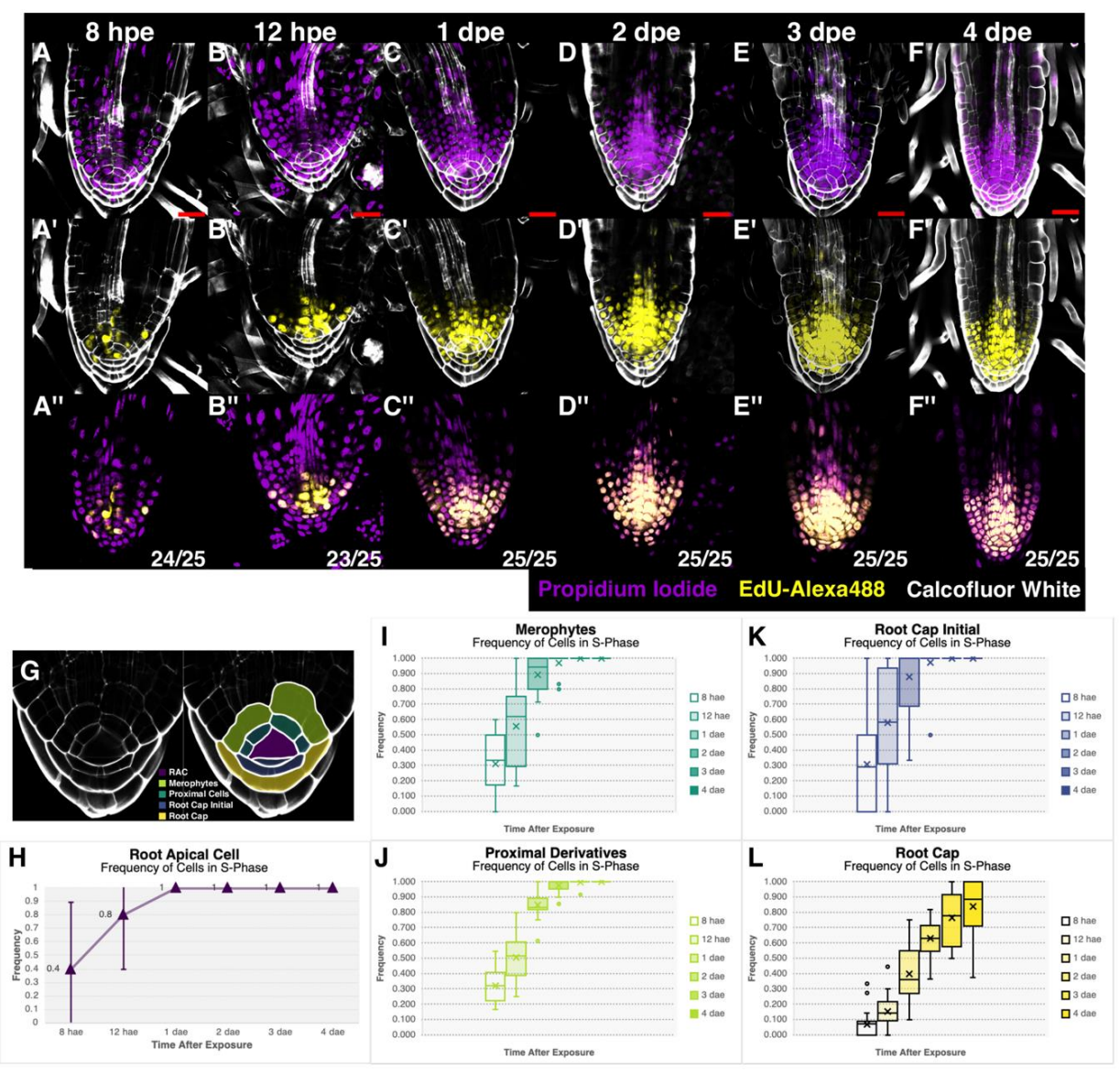

Figure 6. Cellular dynamics of the first shoot-borne root. (A-F) EdU incorporation experiment to detect cells in their S-phase of cell cycle at 8 hae $\left(\mathbf{A}, \mathbf{A}^{\prime}, \mathbf{A}^{\prime \prime}\right), 12$ hae $\left(\mathbf{B}, \mathbf{B}^{\prime}, \mathbf{B}^{\prime \prime}\right), 1$ dae $\left(\mathbf{C}, \mathbf{C}^{\prime}, \mathbf{C}^{\prime \prime}\right)$, 2 dae $\left(\mathbf{D}, \mathbf{D}^{\prime}, \mathbf{D}^{\prime \prime}\right), 3$ dae $\left(\mathbf{E}, \mathbf{E}^{\prime}, \mathbf{E}^{\prime \prime}\right)$, and 4 dae $\left(\mathbf{F}, \mathbf{F}^{\prime}, \mathbf{F}^{\prime \prime}\right)$. (A to F) DNA counterstaining and cell wall staining (Propidium Iodide-Purple; Calcofluor White-White); $\left(\mathbf{A}^{\prime}-\mathbf{F}^{\prime}\right)$ EdU-labeled DNA and cell wall staining (EdU-Alexa488-Yellow; Calcofluor White-White); (A"-F") EdU-labeled DNA and DNA counterstaining merge (EdU-Alexa488-Yellow; Propidium Iodide-Purple). Scale bar: $20 \mu \mathrm{m}$. hae-hours after exposure; dae-days after exposure. Numbers in the right bottom corner of Figure $6 \mathrm{~A}^{\prime \prime}-\mathrm{F}^{\prime \prime}$ : Amount of plants displaying the triple staining/Total amount of plants used in the experiment (G) Established zonation inside the stem cell niche. The following plots represent the average frequency of cells entering the S-phase of the cell cycle in a specific zone of Ceratopteris root apical meristem at different times of EdU incorporation: $(\mathbf{H})$ Scattered plot of the frequency of S-phase cells in the RAC. (I-L) Box plots showing the frequency of entering the S-phase of cell cycle in the different zones of the RAM: merophytes (I); proximal cells (J); root cap initials (K); root cap cells (L). The frequency of cells entering to S-phase was statistically determined with a student's $t$ test for each cell type. Note: brightness of the Alexa- 488 channel in Figure $6 \mathrm{~F}^{\prime \prime}$ was decreased when compared to previous times in order to have a better observation of both merged channels. 
Roots exposed to EdU showed a clear incorporation signal in the nuclei of the different cell types analyzed (Figure $6 \mathrm{~A}^{\prime}-\mathrm{F}^{\prime}$ ). These observations were compared with nuclei counterstaining with propidium iodide (Figure 6A-F). The merged signal between EdU-Alexa488 and PI shows the proper signal position in each nucleus (Figure $\left.6 \mathrm{~A}^{\prime \prime}-\mathrm{F}^{\prime \prime}\right)$. Notably, right after $8 \mathrm{~h}$ of exposure, EdU incorporation was observed in $40 \%$ of analyzed RACs (Figure $6 \mathrm{~F}$ ) as revealed by their stained nuclei (Figure $6 \mathrm{~A}^{\prime}$ ). In subsequent exposure times, more roots displayed a stained RAC nucleus (Figure $6 \mathrm{~B}^{\prime}, \mathrm{H}$ ). From 1 dae, all roots analyzed showed incorporation signal in the RAC (Figure $6 \mathrm{C}^{\prime}-\mathrm{F}^{\prime}, \mathrm{H}$ ). These results suggest that the RAC undergoes constant cell divisions in the SBR-1 of Ceratopteris sporelings. Such developmental behavior of the RAC may indicate that this cell is not mitotically quiescent.

Also, merophytes and proximal daughter cells displayed incorporation signals at early exposure times (Figure $6 \mathrm{~A}^{\prime}$ ). Both types of cells showed a similar incorporation frequency at 8 hae (Figure $6 \mathrm{I}, \mathrm{J}$ ). However, at 12 hae and 1 dae, merophytes displayed an incorporation frequency of $10 \%$ and $5 \%$ faster compared to proximal daughter cells. Merophytes act as progenitors of proximal cells, and they are subjected to repeated rounds of cell division, which may be reflected by a high incorporation frequency. Instead, proximal cells can have a limited number of proliferative divisions depending on the cell layer (Figure S3), which could explain a lower EdU incorporation, compared to merophytes.

The RCI presents a peculiar EdU incorporation pattern (Figure 6K). We detected that the RCI showed more than a nucleus or a continuous cell wall (Figure 6A-F). This may indicate the RCI is subject to proliferative divisions, because we observed up to four different nuclei at this position. The root cap cells exhibited incorporation values from 2 to 4 times slower compared to the other zones in early exposure times (Figure $6 \mathrm{~L}$ ). Additionally, it was the only cell lineage that did not incorporate EdU in all analyzed cells, which suggests that these cells lose their division capacity while distancing from the RAC, probably reaching a differentiated status.

\section{Discussion}

\subsection{How Early is the First Root Specified during Ceratopteris Embryogenesis?}

By delving into early sporophyte development in Ceratopteris richardii, we determined the specification of the first stem-borne root and growth dynamics of its homorhizic root system (Figure 3). The cellular ontogeny of the first SBR has been debated several times. Separate authors proposed different explanations at what stage and from which cell is established [50-53]. Our rigorous observations of the different stages in Ceratopteris embryogenesis suggest that the first root is specified, at least, at the octant stage from the hypobasal outer cells (Figure 2G). From those cells, the distinctive tetrahedral-shaped RAC would be distinguishable in later stages (Figure $2 \mathrm{H}, \mathrm{I}$ ) and the whole RAM would develop (Figure $2 \mathrm{P}^{\prime}$ and Figure $4 \mathrm{~A}$ ). These results show that the early patterning Ceratopteris richardii embryo is similar to other leptosporangiate ferns [54]. In Arabidopsis, root development begins by recruiting the most upper suspensor cell, the hypophysis, which would later give rise to the quiescent center and columella. Even though, Arabidopsis RAM is observable until the late globular stage, the hypophysis is already present since the 8-celled embryo based on the overlapping expression of two homeodomain genes from the WOX family, AthWOX8 and AthWOX9 [55,56]. In Ceratopteris, five different WOX genes were identified, with CriWOXA and CriWOXB belonging in the same clade as those previously mentioned [6,57]. No studies assessing WOX genes in Ceratopteris embryogenesis have been performed yet [57-59]. Transcriptional analyses, transgenesis and reverse genetics approaches in Ceratopteris are necessary to detect key regulators during the embryogenesis, to uncover how early the specification of the root is carried out, and if regulatory networks in this process are conserved between seed plants and ferns.

\subsection{The Ceratopteris Root Develops from a Narrow Multicellular Meristem}

The discrete root zonation exhibits the developmental and cellular processes carried out in each sector. This feature has been well documented from Arabidopsis and other angiosperms to 
pteridophytes $[46,60,61]$. We established the different root zones in the first SBR of Ceratopteris (Figures 4A and 7A), which is composed of a small-sized meristematic zone (Table 1B; Figure 4B) followed by the EDZ. A straightforward separation between the EZ and DZ was not determined: root hair development was not observed right after the MZ but xylem differentiation was noticed (Figure 4B, pink lines). This ambiguous partition between both zones could be a consequence of the developmental stage when Ceratopteris roots were analyzed. According to analysis in other fern species, Azolla filiculoides roots displayed the three different zones, but these roots were produced from a regenerative process. This work was also the first to use the outer cortex layer to measure the cell number in the root meristem of a fern species [60]. Additionally, the most outer cortex layer has been used in different flowering plants that develop several cortical layers, such as Hordeum vulgare [32]. Additionally, Azolla roots presented a larger meristem size (Figure 7B, middle panel) when compared to Ceratopteris roots (Figure 7B, left panel). However, our experiment following the changes of cell number in the Ceratopteris first SBR meristem showed that this feature changes through time (Figure 5A). Still, our results suggest that the root meristem in Ceratopteris is shorter than compared to other species.

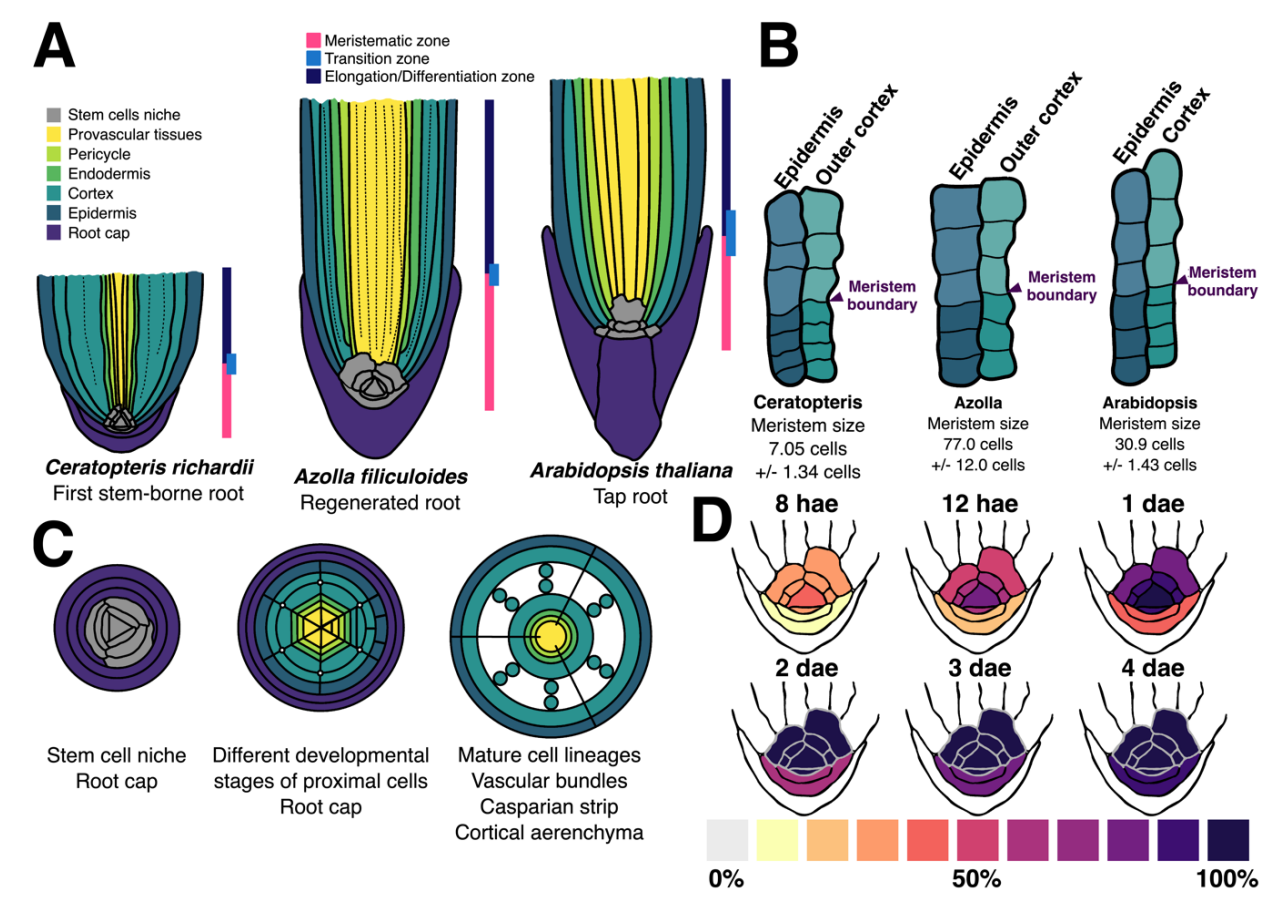

Figure 7. Graphic summary of the cellular organization and division dynamics in the Ceratopteris richardii first stem-borne root. (A) Roots are divided in three zones: meristematic, elongation, and differentiation zone. Ceratopteris root presents two main zones: meristematic and elongation/differentiation zones. The roots of Azolla and Arabidopsis are represented for comparison purposes. (B) In a longitudinal section, the boundary between meristematic and elongation/differentiation zones is established where the cell length begins to expand. For Azolla and Ceratopteris, the outer cortex layer has a reliable morphology. The size of root apical meristem varies considerably among the three species depicted here. (C) Radial organization changes along the longitudinal axis in a shootward manner. The different tissues would mature according to the position and differentiation stage of the merophytes, from one undifferentiated cell to lineage-specific cells: (Left) The RAC and its merophytes are surrounded by root cap cells. (Middle) Cell transitions from merophytes to specific layer initials. (Right) Differentiated tissues with specific traits. (D) Different cell types of the RAM have different cell cycle activity, based on EdU incorporation analysis. The RAC has a higher activity compared to its derivatives. 
Furthermore, Arabidopsis seedlings display a root meristem with an average size of 30.9 cells [61] (Figure 7B, right panel) which could be considered an intermediary from the meristem sizes in fern roots. However, Arabidopsis is a phylogenetically distant plant and even its meristem organization is divergent from ferns and other angiosperms. The dramatic difference in size of the Ceratopteris MZ, 11 and 4 times smaller than Azolla's and Arabidopsis' MZ, respectively, opens up the question of how the meristem size is regulated. The phytohormones, auxin and cytokinin, have shown opposing roles in controlling the meristem size in Arabidopsis [61]. Additionally, the activity of the proteins PHABULOSA (PHB) in the stele and SCARECROW (SCR) in the endodermis have been linked to modulate meristem size by controlling the cytokinin response regulators in the proximal meristem, thus affecting the number of dividing cells and root growth [62,63]. Recent studies reported an orthologous gene for SCR and the presence of PHB gene subfamily (Class III HD-Zip, Type 2) in several fern species [7,64]. Still, the response to hormones in ferns roots doesn't seem to be similar and even opposed to Arabidopsis, which places a challenge regarding the role of these genes in controlling the root meristem size $[25,59,60]$.

The Ceratopteris RAM is composed by the RAC, the proximal merophytes and a distal RCI. This arrangement is maintained since the RAC appearance during embryogenesis to postembryonic development, but the meristem cell number may be changing until reach a steady size (Figures 2M, 4A and 7A). Our morphological analyses showed a consistent organization compared to previous reports on Ceratopteris [25,40]. In addition, the EdU incorporation experiment allows further support to our inference of the localization of an apical meristem in the root (Figure 6 $\mathrm{A}^{\prime \prime}-\mathrm{F}^{\prime \prime}$ ). These results also strengthen the hypothesis of a multicellular meristem since the RAC is constantly producing merophytes and these cells are dividing as initials to generate all tissues. Even though this type of meristem may not fit into the idea of a multicellular meristem, it is because this current concept is based on angiosperms. More evidence about meristem dynamics has been obtained by exploring plant diversity and understanding how this essential part of the plant is functioning in extant lineages [65-68]. Additionally, the meristem organization in Ceratopteris roots is highly conserved in roots of different fern species (Figure 1B, Table S1). Based on our observations, and those reported for other ferns, we suggest that the RAC and its derivatives comprise the stem cell niche of the Ceratopteris root. Still, more experiments are needed to determine hormone gradients, expressed genes and other cues implicated in RSCN activity and maintenance. Noteworthy, exceptions of this consensus morphology are present in other fern species. In some eusporangiate ferns and Osmundales, the RAM has two to four (smaller) apical cells instead of a single RAC [69-71].

Our proposed fern RAM organization contrasts with the RAMs from other major lineages of vascular plants, which exhibit higher morphological diversity. For example, in lycophytes four different types of RAM have been defined, depending on their cellular organization and division frequency [29]. Similar to our findings, the RAMs in the order Selaginellales also have an apical cell at their tip [28]. The presence of this RAM organization in Selaginellales and several orders of ferns could imply different scenarios: (1) meristems with an apical cell were present in the ancestor of vascular plants, later co-opted for root meristems and diversified into a wide range of cellular organizations except for ferns and Selaginellales (Figure 1B); (2) this RAM organization appeared separately in ferns and Selaginella species, and it has been preserved because of its efficient physiology. How an increase in diversity can be gained in the RAMs at the cellular level still remains unanswered and becomes a fascinating subject to unravel specific adaptations at a cellular level.

\subsection{Ceratopteris Root Cell Layers Exhibit the Conservation of Specific Traits}

A root is composed by a diverse set of cell layers, radially organized, each one with its own identity and function $[19,56]$. We focused mainly on detecting specific traits that appear during the maturation of each cell layer and used Hou and Hill report [25] as a reference to examine our results. In this aforementioned study, the transversal organization of the RSCN was uncovered with the RAC and merophytes (from different cell numbers) were at the center and surrounded by root cap cells 
(Figure 7C, left). This organization is localized at the most distal part of the MZ, where merophytes have only been subjected to a couple of proliferative divisions [25,26]. A crucial developmental stage comes after the former (shootwards), and there, the merophytes continued dividing [25] (Figure 7C, middle). The proximal merophytes can be considered transit-amplifying cells as they are still inside the $M Z$ and dividing several times in a precise pattern to generate the diverse cell lineages of the root body (Figure S3). Upon entering the EDZ, we detected a clear concentric organization of the cell layer and each one of these displayed specific traits, which allows the distinction from one another (Figure 7C, right). The diverse set of features analyzed in the EDZ of Ceratopteris roots seems to be conserved with other vascular plants [32,41,56,68,72-77]. This could imply that some cell lineages already existed in the common ancestor of euphyllophytes and suggests the conservation of genetic networks involved in their specification, to some extent, between ferns and seed plants.

We also observed that different tissues differentiate at various developmental positions. The xylem is maturing before leaving the meristematic zone, compared to the outer cortex cells that have not begun yet to elongate (Figure 4B). This variation of the maturation times in the diverse set of root tissues was previously observed in other fern species [78]. In other two species of Ceratopteris, C. pteridoides and C. thalictroides, the vascular tissues were the first lineage to differentiate while the cortical layers were the last ones to maturate. This order of tissue maturation may differ in other species, not even being conserved inside the same family as demonstrated by a different order in Adiantum capillus-veneris and Pteris multifida. Both genera along with Ceratopteris are part of the Pteridaceae family.

The vascular tissues were an important innovation of tracheophytes, they are divided in two different functional domains: xylem and phloem [79]. We detected the presence of lignin at the center of Ceratopteris roots, which demonstrate the localization of the xylem. Additionally, a differential signal intensity and cellular morphology made discernable xylem types: metaxylem, higher staining signal and wider cells; and protoxylem, minor signal and smaller cells. This could be a consequence of a greater lignin accumulation due to an advanced maduration state [77,80]. We did not detect a specific trait of phloem, but unstained cells adjacent to xylem cells correspond to this tissue. Another study reported two different antibodies binding preferentially to pectin or hemicellulose present in the phloem, and that can be used in future research to differentiate this layer [81].

The endodermis bears a Casparian strip, which is composed by lignin and lower amounts of suberin [73]. We observed the CS at the center of transversal and anticlinal cell walls in the fifth cell layer (Figure 4D'). The CS was previously observed in other Ceratopteris species and different ferns [78,82]. The endodermis has been constantly present in euphyllophytes roots for millions of years, probably due to its function in water and nutrient transport. Interestingly, the roots of Lycopodium species (Lycodiopsida) were reported to lack a CS, thus neither an endodermis [83].

The root cap is a common feature of vascular plants. This tissue is considered a main innovation in roots because it protects the RSCN [84]. We detected the presence of amyloplasts in the root cap zone of Ceratopteris, and low signal was also observed within the root apex (Figure 3F). Amyloplasts have been found in other ferns, in the root cap of Regnellidium diphyllum and in the stele of A. filiculoides roots $[60,85]$. Noteworthy, a recent report concluded that the role of amyloplasts in gravitropic response is absent in the roots of ferns and lycophytes [86].

While some studies have begun to unravel the developmental role of certain genes in Ceratopteris and other ferns, none of them focused on root cell layers specification $[7,13,58,59,65,66,87-90]$. Unsurprisingly, the genetic networks involved in root cell layers have been mainly described in Arabidopsis $[56,64,84]$. We already speculated the possible or partial conservation of gene function in cell layer specification of ferns and angiosperms roots. One example in Ceratopteris root might be the specification of middle cortex and endodermis from a common merophyte derivative (Figure S3). In Arabidopsis root, a single initial is present for both ground tissue layers, where AthSCR and its partner SHORTROOT (AthSHR) have been widely characterized as essential effectors in the specification process (Bennett and Scheres, 2010; Motte et al., 2020). Their orthologous genes are expressed in Azolla root tip, which could indicate the conservation of this network, considering more 
genes are involved [60]. Fern orthologs for other genes expressed during Arabidopsis root development have been reported: the Class III HD-Zips and VND genes involved in xylem differentiation were detected in Azolla root and the leaves of other fern species [7,60]; KANADI genes implicated in phloem development were identify in Equisetum hyemale leaves [91]; the NAC domain genes, FEZ and $S O M B R E R O$, required for root cap development, were detected to be preferentially expressed in the MZ of six different plants, including the lycophyte Selaginella [46]. Still, not all structural orthologs found in Ceratopteris have the "complete" function from their equivalents in Arabidopsis, such as CriWUL and CriPINJ, a WUSCHEL ortholog and the sole ortholog for the extensively duplicated Eu3-PIN clade $[86,90,92]$. The specification of cell layers poses the possibility to explore the conservation and divergence of the genetic networks that define cell lineages.

\subsection{Ceratopteris Stem-Borne Roots Display Growth Cessation}

Ceratopteris establishes a complex organization of its homorhizic root system throughout development. Hou and Hill [40] followed the growth behavior of six SBRs and focused on determining their heteroblastic development and growth rate. Our approach explored the emergence and growth of Ceratopteris SBRs for 30 days after the first root emerged (Figure 5B), while examining the timeline of the root system establishment and growth behavior in solid media. We detected that root emergence time is shortened between consecutive SBRs. We propose two possible explanation for this phenomenon: (1) a wider leaf area available for photosynthesis would produce higher amounts of photosynthates available to develop other organs; (2) a more complex root system would allow a more efficient water and nutrient uptake, allowing faster organ formation. At the last time registered (30 days of growth), we still observed a small change in root length. While this modest root growth was found to be statically significant in our results (Figure 5B), we propose it may not be caused due to an active meristematic growth but to remaining developmental processes, such as cell elongation, as it has been described for in the roots of other fern species [93-95]. We observed the cessation of root growth, following a decrease in growth rate, in the earliest SBRs compared to recently-emerged roots. Hou and Hill [40] found a similar outcome while Ceratopteris plants growing in liquid media, which lead us to conclude that media firmness has little to none effect on root growth.

The termination of root growth suggests that Ceratopteris SBRs follow a determinate growth program, even in the presence of nutritional sufficiency. This is concordant with the concept of primary homorhizy indicating that, at least, the first SBR has a short time span [42]. Determinate growth has been shown in different groups of angiosperms. Some cacti species display a constitutive determinate program in their primary root, that is considered an adaptation to severe drought. This process is characterized by the spontaneous RAM exhaustion: reduction of the proximal meristem; root hair development at the root tip; increased lateral root formation; terminal differentiation of the RSCN. The Stenocereus gummosus roots (Cactaceae) have been studied to understand the molecular mechanisms underlying a determinate program. This developmental process can be induced in Arabidopsis roots by nutrient deficiency, redox state and other detrimental stimuli. The root meristem exhaustion in Stenocereus recapitulates the developmental zonation of Arabidopsis. Stenocereus roots at terminal stage displayed a similar transcriptional profile to the differentiation zone of Arabidopsis, where genes involved stemness and proliferation are downregulated [31,96-98].

Azolla roots also showed a determinate program, the RAC was found to divide around 55 times. No morphological changes were reported in mature Azolla roots besides a progressive diminution of plasmodesmata connections [99]. The RAC is mentioned as a consistent trait of the RAM in young and mature roots [26], which supports our hypothesis of the RAC as an organizing center. The omnipresence of the RAC in mature roots of Equisetum scirpoides and Marsilea vestita have been indirectly reported $[93,100]$. This could suggest that the root determinate program does not display major morphological changes and is a consensus behavior in ferns, including Ceratopteris. Still, further research should evaluate what leads the RAC towards an inactive cell cycle, the mechanical 
importance of the RAC shape even in the absence of new divisions, and the overall developmental and physiological changes that define root determinacy in Ceratopteris.

\subsection{The Ceratopteris RAC Exhibits High Mitotic Activity}

The RAM is considered a self-preserving tissue that defines the continuous development of different tissues [2]. We used DNA replication as a molecular marker to detect cell cycle progression, and the EdU is an arabinosyl nucleoside that allows the detection of cells entering to the S-phase of the cell cycle $[29,48,49]$. Our analysis of Ceratopteris root meristem dynamics demonstrated that the RAC has a high division frequency because of signal detection at early treatment times (Figure 7D [8 hae]). This indicates an active cell cycle in the RAC and a higher activity than its immediate derivatives (Figure 7D, upper panel), which is consistent with the RAC histogenetic role [25]. Nevertheless, other studies have concluded that the RAC in ferns is capable to enter mitosis due to the detection of mitotic figures and by the use of colchicine that blocked the competition of the cell cycle in the RAC $[95,99,101]$. All these evidences demonstrate that Ceratopteris RAC is not quiescent. However, because of its position in the RSCN, we propose that the RAC acts as an organizing center that receives and produces different signals to coordinate proper organ formation. Still further research would allow to understand how the RAC may be functioning due to the role of phytohormones or the expression of RAC-enriched genes.

Merophytes are an important feature to acknowledge in fern meristem. These cells are essential morphological units for the root proper formation and the immediate derivatives of the RAC [102]. The proximal merophytes and the RCI showed a slower incorporation frequency compared to the RAC at the earlier exposure times (Figure 7D, upper panel). A similar observation was reported in Marsilea and Azolla, where the RAC displays a higher cell division frequency compared to the merophytes [93,94]. Additionally, the RAC of Ceratopteris and Marsilea constantly produces merophytes at both proximal and distal planes, while Azolla's RAC has only the capacity to generate proximal merophytes [25,93,94]. Several questions regarding the functionality of these cell units regard unanswered: how merophytes do function to generate all different lineages in the proximal body?; which is the genetic program in charge of specifying them?; does the genetic program differs in order to generate proximal and distal merophytes?

The dynamics observed in Ceratopteris RAM offers the possibility to assess how genetic networks and different signals operate to maintain a constantly dividing stem cell niche. Auxins were found to play an important role during root initiation in Ceratopteris. Genes involved in the cell cycle, DNA replication and chromatin remodeling are upregulated after one day of treating Ceratopteris sporelings with exogenous auxins. Orthologous genes for the WOX, GRAS and PIN gene families, well-known RSCN regulators, were also activated [56,59]. CriWOXA was found as a direct target from auxin response and transiently expressed in the root apical mother cell. CriWOXA will later active CriWUL expression in one-celled merophytes [57,59]. However, both genes were not expressed in the same cell. A possibility is CriWOXA movement to adjacent cells to form a protein gradient that allows the activation of CriWUL and other genes. An Arabidopsis ortholog behaves in this manner: AthWOX5 is expressed in the QC and its protein moves towards stele and columella initials [103]. Still the presence of hormone gradient and the actual roles of genes involved in Ceratopteris root development and RAM dynamics remain to be elucidated.

A fine-tune explanation for each developmental process observed in our results demands an extended knowledge of Ceratopteris richardii. Whilst we provided a comprehensive description of Ceratopteris stem-borne roots during their development, collectively with previous studies [14,40], we have contributed to a more complete framework of Ceratopteris developmental stages. Hence, this fern could be used to assess the cellular and molecular mechanisms in fern root development that remains unexplained. Additionally, Ceratopteris stands as a major model plant for evo-devo studies due to its evolutionary position in the plant phylogeny [1]. Thus, ferns have entered the modern era of 
plant science, with Ceratopteris as a compelling sidekick to explore the diverse evolutionary paths that this lineage have undergone in their history on Earth.

Supplementary Materials: The following are available online at http://www.mdpi.com/2073-4425/11/12/1455/s1, Figure S1. Bright-field images of gametophyte-to-sporophyte transition and embryo development in Ceratopteris richardii; Figure S2. Graphic representation of different planes in a hermaphrodite gametophyte; Figure S3. Schematic representation of cell ontogeny in the root body. Table S1. Vascular plant species analyzed to generate Figure 1A; Table S2. Root growth rate for each stem-borne root according to a five-day timespan.

Author Contributions: Conceptualization, A.A.-R., L.H.-E. and A.C.-R.; experimental design, A.A.-R., L.H.-E. and A.C.-R.; experimental analysis, A.A.-R.; formal analysis, A.A.-R. and A.C.-R.; writing-original draft preparation, A.A.-R. and A.C.-R.; writing - review and editing, all authors; visualization, A.A.-R.; supervision, L.H.-E. and A.C.-R. All authors contributed to the discussion. All authors have read and agreed to the published version of the manuscript.

Funding: This research received no external funding. A.A.-R. was financially supported by a CONACyT PhD Fellowship (No. 421596).

Acknowledgments: We thank Jane Langdale and Andrew Plackett (Oxford University), and Pamela Soltis, Doug Soltis and Blaine Marchant (University of Florida), for providing us with Ceratopteris richardii Hn-n spores. To our lab manager Annie Espinal-Centeno for obtaining the first batch of Ceratopteris spores to begin with this project.

Conflicts of Interest: The authors declare no conflict of interest.

$\begin{array}{ll}\text { Abbreviations } \\ \text { RAM } & \text { Root Apical Meristem } \\ \text { RAC } & \text { Root Apical Cell } \\ \text { RCI } & \text { Root Cap Initial } \\ \text { RSCN } & \text { Root Stem Cell Niche } \\ \text { SBR } & \text { Stem-Borne Root } \\ \text { QC } & \text { Quiescent Center } \\ \text { dps } & \text { days post sowing } \\ \text { daf } & \text { days after fertilization } \\ \text { hae } & \text { hours after exposure } \\ \text { dae } & \text { days after exposure } \\ \text { RGR } & \text { Root Growth Rate } \\ \text { EdU } & \text { 5-ethynyl-2'-deoxyuridine } \\ \text { PI } & \text { Propidium Iodide } \\ \text { CW } & \text { Calcofluor White } \\ \text { MZ } & \text { Meristematic Zone } \\ \text { EDZ } & \text { Elongation-Differentiation Zone }\end{array}$

\section{References}

1. Delaux, P.-M.; Hetherington, A.J.; Coudert, Y.; Delwiche, C.; Dunand, C.; Gould, S.; Kenrick, P.; Li, F.-W.; Philippe, H.; Rensing, S.A.; et al. Reconstructing trait evolution in plant evo-devo studies. Curr. Biol. 2019, 29, R1110-R1118. [CrossRef]

2. Fujinami, R.; Yamada, T.; Imaichi, R. Root apical meristem diversity and the origin of roots: Insights from extant lycophytes. J. Plant Res. 2020, 133, 291-296. [CrossRef]

3. Hetherington, A.J.; Dolan, L. Stepwise and independent origins of roots among land plants. Nature 2018, 561, 235-238. [CrossRef]

4. Kenrick, P.; Strullu-Derrien, C. The origin and early evolution of roots. Plant Physiol. 2014, 166, 570-580. [CrossRef] [PubMed]

5. Raven, J.A.; Edwards, D. Roots: Evolutionary origins and biogeochemical significance. J. Exp. Bot. 2001, 52 (Suppl. 1), 381-401. [CrossRef] [PubMed]

6. Liu, W.; Xu, L. Recruitment of IC-WOX Genes in Root Evolution. Trends Plant Sci. 2018, 23, 490-496. [CrossRef] [PubMed] 
7. Vasco, A.; Smalls, T.L.; Graham, S.W.; Cooper, E.D.; Wong, G.K.-S.; Stevenson, D.W.; Moran, R.C.; Ambrose, B.A. Challenging the paradigms of leaf evolution: Class III HD-Zips in ferns and lycophytes. New Phytol. 2016, 212, 745-758. [CrossRef] [PubMed]

8. Bui, L.T.; Cordle, A.R.; Irish, E.E.; Cheng, C.L. Transient and stable transformation of Ceratopteris richardii gametophytes. BMC Res. Notes 2015, 8, 214. [CrossRef] [PubMed]

9. Hickok, L.G.; Warne, T.R.; Fribourg, R.S. The biology of the fern Ceratopteris and its use as a model system. Int. J. Plant Sci. 1995, 156, 332-345. [CrossRef]

10. Marchant, D.B. Ferns with Benefits: Incorporating Ceratopteris into the Genomics Era. Am. Fern J. 2019, 109, 183. [CrossRef]

11. Marchant, D.B.; Sessa, E.B.; Wolf, P.G.; Heo, K.; Barbazuk, W.B.; Soltis, P.S.; Soltis, D.E. The C-Fern (Ceratopteris richardii) genome: Insights into plant genome evolution with the first partial homosporous fern genome assembly. Sci. Rep. 2019, 9, 1-14. [CrossRef] [PubMed]

12. Plackett, A.R.G.; Huang, L.; Sanders, H.L.; Langdale, J.A. High-efficiency stable transformation of the model fern species Ceratopteris richardii via microparticle bombardment. Plant Physiol. 2014, 165, 3-14. [CrossRef] [PubMed]

13. Plackett, A.R.G.; Conway, S.J.; Hazelton, K.D.H.; Rabbinowitsch, E.H.; Langdale, J.A.; di Stilio, V.S. LEAFY maintains apical stem cell activity during shoot development in the fern ceratopteris richardii. Elife 2018, 7, 1-34. [CrossRef] [PubMed]

14. Conway, S.J.; di Stilio, V.S. An ontogenetic framework for functional studies in the model fern Ceratopteris richardii. Dev. Biol. 2020, 457, 20-29. [CrossRef] [PubMed]

15. Hetherington, A.J.; Dolan, L. The evolution of lycopsid rooting structures: Conservatism and disparity. New Phytol. 2017, 215, 538-544. [CrossRef] [PubMed]

16. Hetherington, A.J.; Dolan, L. Bilaterally symmetric axes with rhizoids composed the rooting structure of the common ancestor of vascular plants. Philos. Trans. R. Soc. B Biol. Sci. 2018, 373, 20170042. [CrossRef]

17. Hetherington, A.J.; Dolan, L. Rhynie chert fossils demonstrate the independent origin and gradual evolution of lycophyte roots. Curr. Opin. Plant Biol. 2019, 47, 119-126. [CrossRef]

18. Kenrick, P. The origin of roots. In Plant Roots: The Hidden Half, 4th ed.; Fourth, E., Eshel, A., Beeckman, T., Eds.; CRC Press: Boca Raton, FL, USA, 2013; pp. 3-16.

19. Dolan, L.; Janmaat, K.; Willemsen, V.; Linstead, P.; Poethig, S.; Roberts, K.; Scheres, B. Cellular organisation of the Arabidopsis thaliana root. Development 1993, 119, 71-84.

20. Ron, M.; Dorrity, M.W.; De Lucas, M.; Toal, T.; Hernandez, R.I.; Little, S.A.; Maloof, J.; Kliebenstein, D.J.; Brady, S.M. Identification of novel loci regulating interspecific variation in root morphology and cellular development in tomato. Plant Physiol. 2013, 162, 755-768. [CrossRef]

21. Ni, J.; Shen, Y.; Zhang, Y.; Wu, P. Definition and stabilisation of the quiescent centre in rice roots. Plant Biol. 2014, 16, 1014-1019. [CrossRef]

22. Seago, J.L.; Fernando, D.D. Anatomical aspects of angiosperm root evolution. Ann. Bot. 2013, 112, $223-238$. [CrossRef] [PubMed]

23. Pillai, A. Root apical organization in gymnosperms—some cycads and Ginkgo biloba. Proc. Indian Acad. Sci. 1962, 57, 211-222.

24. Peterson, C.A.; Enstone, D.E.; Taylor, J.H. Pine root structure and its potential significance for root function. Plant Soil 1999, 217, 205-213. [CrossRef]

25. Hou, G.-C.; Hill, J.P. Developmental anatomy of the fifth shoot-borne root in young sporophytes of Ceratopteris richardii. Planta 2004, 219, 212-220. [CrossRef]

26. Gunning, B.E.S.; Hughes, J.E.; Hardham, A.R. Formative and proliferative cell divisions, cell differentiation, and developmental changes in the meristem of Azolla roots. Planta 1978, 143, 121-144. [CrossRef]

27. Gifford, E.M. The Root Apical Meristem of Equisetum diffusum: Structure and Development. Am. J. Bot. 1993, 80, 468. [CrossRef]

28. Otreba, P.; Gola, E.M. Specific intercalary growth of rhizophores and roots in Selaginella kraussiana (Selaginellaceae) is related to unique dichotomous branching. Flora Morphol. Distrib. Funct. Ecol. Plants 2011, 206, 227-232. [CrossRef]

29. Fujinami, R.; Yamada, T.; Nakajima, A.; Takagi, S.; Idogawa, A.; Kawakami, E.; Tsutsumi, M.; Imaichi, R. Root apical meristem diversity in extant lycophytes and implications for root origins. New Phytol. 2017, 215, 1210-1220. [CrossRef] 
30. Evkaikina, A.I.; Berke, L.; Romanova, M.A.; Proux-Wéra, E.; Ivanova, A.N.; Rydin, C.; Pawlowski, K.; Voitsekhovskaja, O.V. The Huperzia selago shoot tip transcriptome sheds new light on the evolution of leaves. Genome Biol. Evol. 2017, 9, 2444-2460. [CrossRef]

31. Rodríguez-Rodríguez, J.F.; Shishkova, S.; Napsucialy-Mendivil, S.; Dubrovsky, J.G. Apical meristem organization and lack of establishment of the quiescent center in Cactaceae roots with determinate growth. Planta 2003, 217, 849-857. [CrossRef]

32. Kirschner, G.K.; Stahl, Y.; von Korff, M.; Simon, R. Unique and Conserved Features of the Barley Root Meristem. Front. Plant Sci. 2017, 8, 1240. [CrossRef] [PubMed]

33. Deshpande, B.D.; Bahtnagar, P. Apical Meristems of Ephedra foliata. Int. J. Plant Sci. 1961, 122, $279-284$. [CrossRef]

34. Allen, G.S. Embryogeny and the Development of the Apical Meristems of Pseudotsuga. III. Development of the Apical Meristems. Am. J. Bot. 1947, 34, 204-211. [CrossRef]

35. Johnson-Flanagan, A.M.; Owens, J.N. Development of white spruce (Picea glauca) seedling roots. Can. J. Bot. 1985, 63, 456-462. [CrossRef]

36. Hetherington, A.J.; Dubrovsky, J.G.; Dolan, L. Unique Cellular Organization in the Oldest Root Meristem. Curr. Biol. 2016, 26, 1629-1633. [CrossRef]

37. Bhambie, S.; Prakasa, C.G. Rao Studies in Pteridophytes IX. The Root Apex Organization in Some Pteridophytes. Proc. Plant Sci. 1972, 39, 150-156.

38. Chapple, C.C.S.; Peterson, R.L. Root Structure in the Fern Platycerium bifurcatum (Cav.) C. Chr. (Polypodiaceae). Int. J. Plant Sci. 1987, 148, 180-187. [CrossRef]

39. Pillai, A. Root apical organization in gymnosperms. Planta 1966, 70, 26-33. [CrossRef]

40. Hou, G.; Hill, J.P. Heteroblastic Root Development in Ceratopteris richardii (Parkeriaceae). Int. J. Plant Sci. 2002, 163, 341-351. [CrossRef]

41. Heimsch, C.; Seago, J.L. Organization of the root apical meristem in angiosperms. Am. J. Bot. 2008, 95, 1-21. [CrossRef]

42. Schneider, H. Evolutionary Morphology of Ferns (Monilophytes). Evol. Plant Form 2012, 45, 115-140.

43. Scheres, B.; Wolkenfelt, H.; Willemsen, V.; Terlouw, M.; Lawson, E.; Dean, C.; Weisbeek, P. Embryonic origin of the Arabidopsis primary root and root meristem initials. Development 1994, 120, 2475-2487.

44. Warne, T.R.; Lloyd, R.M. The Role of Spore Germination and Gametophyte Development in Habitat Selection: Temperature Responses in Certain Temperature and Tropical Ferns. Torrey Bot. Soc. 1980, 107, 57-64. [CrossRef]

45. Kurihara, D.; Mizuta, Y.; Sato, Y.; Higashiyama, T. ClearSee: A rapid optical clearing reagent for whole-plant fluorescence imaging. Development 2015, 142, 4168-4179. [CrossRef]

46. Huang, L.; Schiefelbein, J. Conserved gene expression programs in developing roots from diverse plants. Plant Cell 2015, 27, 2119-2132. [CrossRef]

47. Lux, A.; Morita, S.; Abe, J.; Ito, K. An improved method for clearing and staining free-hand sections and whole-mount samples. Ann. Bot. 2005, 96, 989-996. [CrossRef]

48. Cruz-Ramírez, A.; Díaz-Triviño, S.; Wachsman, G.; Du, Y.; Arteága-Vázquez, M.; Zhang, H.; Benjamins, R.; Blilou, I.; Neef, A.B.; Chandler, V.; et al. A SCARECROW-RETINOBLASTOMA Protein Network Controls Protective Quiescence in the Arabidopsis Root Stem Cell Organizer. PLoS Biol. 2013, 11. [CrossRef]

49. Neef, A.B.; Luedtke, N.W. Dynamic metabolic labeling of DNA in vivo with arabinosyl nucleosides. Proc. Natl. Acad. Sci. USA 2011, 108, 20404-20409. [CrossRef]

50. Johnson, G.P.; Renzaglia, K.S. Embryology of Ceratopteris richardii (Pteridaceae, tribe Ceratopterideae), with emphasis on placental development. J. Plant Res. 2008, 121, 581-592. [CrossRef]

51. Wardlaw, C.W. Embryogenesis in Plants; Methuen: London, UK, 1955.

52. DeMaggio, A.E. Cytological Aspects of Reproduction in Ferns. Bot. Rev. 1977, 43, 427-448. [CrossRef]

53. Chiang, Y.-L.; Chiang, S.-H.T. The Sporeling of Ceratopteris. Taiwania 1960, 8, 35-50.

54. Johnson, G.P.; Renzaglia, K.S. Evaluating the diversity of pteridophyte embryology in the light of recent phylogenetic analyses leads to new inferences on character evolution. Plant Syst. Evol. 2009, 283, 149-164. [CrossRef]

55. Jenik, P.D.; Gillmor, C.S.; Lukowitz, W. Embryonic patterning in Arabidopsis thaliana. Annu. Rev. Cell Dev. Biol. 2007, 23, 207-236. [CrossRef] [PubMed] 
56. Bennett, T.; Scheres, B. Root development-two meristems for the price of one? Curr. Top. Dev. Biol. 2010, 91, 67-102. [PubMed]

57. Nardmann, J.; Werr, W. The invention of WUS-like stem cell-promoting functions in plants predates leptosporangiate ferns. Plant Mol. Biol. 2012, 78, 123-134. [CrossRef] [PubMed]

58. Youngstrom, C.E.; Geadelmann, L.F.; Irish, E.E.; Cheng, C.L. A fern WUSCHEL-RELATED HOMEOBOX gene functions in both gametophyte and sporophyte generations. BMC Plant Biol. 2019, 19, 416. [CrossRef]

59. Yu, J.; Zhang, Y.; Liu, W.; Wang, H.; Wen, S.; Zhang, Y.; Xu, L. Molecular evolution of auxin-mediated root initiation in plants. Mol. Biol. Evol. 2019, 37, 1-19. [CrossRef]

60. De Vries, J.; Fischer, A.M.; Roettger, M.; Rommel, S.; Schluepmann, H.; Bräutigam, A.; Carlsbecker, A.; Gould, S.B. Cytokinin-induced promotion of root meristem size in the fern Azolla supports a shoot-like origin of euphyllophyte roots. New Phytol. 2016, 209, 705-720. [CrossRef]

61. Perilli, S.; Sabatini, S. Analysis of Root Meristem Size Development. Plant Dev. Biol. 2010, 655, $177-187$.

62. Moubayidin, L.; Salvi, E.; Giustini, L.; Terpstra, I.; Heidstra, R.; Costantino, P.; Sabatini, S. A SCARECROW-based regulatory circuit controls Arabidopsis thaliana meristem size from the root endodermis. Planta 2016, 243, 1159-1168. [CrossRef]

63. Sebastian, J.; Ryu, K.H.; Zhou, J.; Tarkowská, D.; Tarkowski, P.; Cho, Y.; Yoo, S.; Kim, E.; Lee, J. PHABULOSA Controls the Quiescent Center-Independent Root Meristem Activities in Arabidopsis thaliana. PLoS Genet. 2015, 11, e1004973. [CrossRef] [PubMed]

64. Motte, H.; Parizot, B.; Fang, T.; Beeckman, T. The evolutionary trajectory of root stem cells. Curr. Opin. Plant Biol. 2020, 53, 23-30. [CrossRef] [PubMed]

65. Ambrose, B.A.; Vasco, A. Bringing the multicellular fern meristem into focus. New Phytol. 2016, $210,790-793$. [CrossRef]

66. Cruz, R.; Melo-De-pinna, G.F.A.; Vasco, A.; Prado, J.; Ambrose, B.A. Class I KNOX is related to determinacy during the leaf development of the fern Mickelia scandens (Dryopteridaceae). Int. J. Mol. Sci. 2020, 21, 4295. [CrossRef] [PubMed]

67. Ferrari, C.; Shivhare, D.; Hansen, B.O.; Pasha, A.; Esteban, E.; Provart, N.J.; Kragler, F.; Fernie, A.R.; Tohge, T.; Mutwil, M. Expression atlas of selaginella moellendorffii provides insights into the evolution of vasculature, secondary metabolism, and roots. Plant Cell 2020, 32, 853-870. [CrossRef] [PubMed]

68. Imaichi, R.; Moritoki, N.; Solvang, H.K. Evolution of root apical meristem structures in vascular plants: Plasmodesmatal networks. Am. J. Bot. 2018, 105, 1453-1468. [CrossRef] [PubMed]

69. Freeberg, J.A.; Gifford, E.M. The Root Apical Meristem of Osmunda regalis. Am. J. Bot. 1984, 71, 558-563. [CrossRef]

70. White, R.A.; Turner, M.D. Anatomy and development of the fern sporophyte. Bot. Rev. 1995, 61, $281-305$. [CrossRef]

71. Gifford, E.M. Concept of Apical Cells in Bryophytes and Pteridophytes. Annu. Rev. Plant Physiol. 1983, 34, 419-440. [CrossRef]

72. Barlow, P.W. The Root Cap: Cell Dynamics, Cell Differentiation and Cap Function. J. Plant Growth Regul. 2003, 21, 261-286. [CrossRef]

73. Geldner, N. The Endodermis. Annu. Rev. Plant Biol. 2013, 64, 531-558. [CrossRef] [PubMed]

74. Jung, J.; Lee, S.C.; Choi, H.K. Anatomical patterns of aerenchyma in aquatic and wetland plants. J. Plant Biol. 2008, 51, 428-439. [CrossRef]

75. Pires, N.D.; Dolan, L. Morphological evolution in land plants: New designs with old genes. Philos. Trans. R. Soc. B Biol. Sci. 2012, 367, 508-518. [CrossRef] [PubMed]

76. Takahashi, H.; Yamauchi, T.; Colmer, T.D.; Nakazono, M. Aerenchyma Formation in Plants. Plant Cell Monogr. 2014, 21, 247-265. [CrossRef]

77. Lucas, W.J.; Groover, A.; Lichtenberger, R.; Furuta, K.; Yadav, S.R.; Helariutta, Y.; Patrick, J.W. The Plant Vascular System: Evolution, Development and Functions. J. Integr. Plant Biol. 2013, 55, 294-388. [CrossRef]

78. Chiang, S.-H.T.; Chou, T. Tissue Differentiation in the Roots of Some Ferns. Taiwania 1974, 19, 7-18.

79. Pittermann, J.; Watkins, J.E.; Cary, K.L.; Schuettpelz, E.; Brodersen, C.R.; Smith, A.R.; Baer, A. The Structure and Function of Xylem in Seed-Free Vascular Plants: An Evolutionary Perspective. In Functional and Ecological Xylem Anatomy; Springer International Publishing: Cham, Switzerland, 2015; pp. 1-37.

80. De Rybel, B.; Mähönen, A.P.; Helariutta, Y.; Weijers, D. Plant vascular development: From early specification to differentiation. Nat. Rev. Mol. Cell Biol. 2016, 17, 30-40. [CrossRef] 
81. Eeckhout, S.; Leroux, O.; Willats, W.G.T.; Popper, Z.A.; Viane, R.L.L. Comparative glycan profiling of Ceratopteris richardii 'C-Fern' gametophytes and sporophytes links cell-wall composition to functional specialization. Ann. Bot. 2014, 114, 1295-1307. [CrossRef]

82. PriestleyI, J.H.; Radcliffe, F.M. A Study in the Endodermis in the Filicineae. New Phytol. 1924, 23, 161-193. [CrossRef]

83. Damus, M.; Peterson, R.L.; Enstone, D.E.; Peterson, C.A. Modifications of cortical cell walls in roots of seedless vascular plants. Bot. Acta 1997, 110, 190-195. [CrossRef]

84. Kumpf, R.P.; Nowack, M.K. The root cap: A short story of life and death. J. Exp. Bot. 2015, 66, 5651-5662. [CrossRef] [PubMed]

85. Eastman, A.; Peterson, R.L. Root Apex Structure in Regnellidium diphyllum (Marsileaceae). Int. J. Plant Sci. 1985, 146, 44-55. [CrossRef]

86. Zhang, Y.; Xiao, G.; Wang, X.; Zhang, X.; Friml, J. Evolution of fast root gravitropism in seed plants. Nat. Commun. 2019, 10, 4-13. [CrossRef] [PubMed]

87. Bui, L.T.; Pandzic, D.; Youngstrom, C.E.; Wallace, S.; Irish, E.E.; Szövényi, P.; Cheng, C. A fern AINTEGUMENTA gene mirrors BABY BOOM in promoting apogamy in Ceratopteris richardii. Plant J. 2017, 90, 122-132. [CrossRef] [PubMed]

88. Hasebe, M.; Wen, C.K.; Kato, M.; Banks, J.A. Characterization of MADS homeotic genes in the fern Ceratopteris richardii. Proc. Natl. Acad. Sci. USA 1998, 95, 6222-6227. [CrossRef]

89. Sano, R.; Juarez, C.M.; Hass, B.; Sakakibara, K.; Ito, M.; Banks, J.A.; Hasebe, M. KNOX homeobox genes potentially have similar function in both diploid unicellular and multicellular meristems, but not in haploid meristems. Evol. Dev. 2005, 7, 9-78. [CrossRef]

90. Zhang, Y.; Jiao, Y.; Jiao, H.; Zhao, H.; Zhu, Y.X. Two-step functional innovation of the stem-cell factors WUS/WOX5 during plant evolution. Mol. Biol. Evol. 2017, 34, 640-653. [CrossRef]

91. Zumajo-Cardona, C.; Vasco, A.; Ambrose, B.A. The Evolution of the KANADI Gene Family and Leaf Development in Lycophytes and Ferns. Plants 2019, 8, 313. [CrossRef]

92. Bennett, T.; Brockington, S.F.; Rothfels, C.; Graham, S.W.; Stevenson, D.; Kutchan, T.; Rolf, M.; Thomas, P.; Wong, G.K.-S.; Leyser, O.; et al. Paralogous radiations of PIN proteins with multiple origins of noncanonical PIN structure. Mol. Biol. Evol. 2014, 31, 2042-2060. [CrossRef]

93. Kurth, E. Mitotic Activity in the Root Apex of the Water Fern Marsilea vestita Hook. and Grev. Am. J. Bot. 1981, 68, 881-896. [CrossRef]

94. Kurth, E.; Gifford, E.M. Ontogenetic Changes in DNA Content in Roots of the Water Fern Azolla filiculoides. Am. J. Bot. 1985, 72, 1676-1683. [CrossRef]

95. Nitayangkura, S.; Gifford, E.M.; Rost, T.L. Mitotic Activity in the Root Apical Meristem of Azolla filiculoides Lam., with Special Reference to the Apical Cell. Bot. Soc. Am. 1980, 67, 1484-1492. [CrossRef]

96. Benesova, S. Development Related Termination of the Root Apical Meristem Activity. Master's Thesis, Experimental Plant Biology. Charles University in Prague Faculty of Science, Nové Město, Czech Republic, 2016.

97. Gutiérrez-Alanís, D.; Yong-Villalobos, L.; Jiménez-Sandoval, P.; Alatorre-Cobos, F.; Oropeza-Aburto, A.; Mora-Macías, J.; Sánchez-Rodríguez, F.; Cruz-Ramírez, A.; Herrera-Estrella, L. Phosphate Starvation-Dependent Iron Mobilization Induces CLE14 Expression to Trigger Root Meristem Differentiation through CLV2/PEPR2 Signaling. Dev. Cell 2017, 41, 555-570.e3. [CrossRef] [PubMed]

98. Rodriguez-Alonso, G.; Matvienko, M.; López-Valle, M.L.; Lázaro-Mixteco, P.E.; Napsucialy-Mendivil, S.; Dubrovsky, J.G.; Shishkova, S. Transcriptomics insights into the genetic regulation of root apical meristem exhaustion and determinate primary root growth in Pachycereus pringlei (Cactaceae). Sci. Rep. 2018, 8, 1-11. [CrossRef]

99. Gunning, B.E.S. Age-related and origin-related control of the numbers of plasmodesmata in cell walls of developing Azolla roots. Planta 1978, 143, 181-190.

100. Gifford, E.M.; Kurth, E. Quantitative Studies of the Root Apical Meristem of Equisetum scirpoides. Am. J. Bot. 1982, 69, 464. [CrossRef]

101. Chiang, S.-H.T. The Time of Mitosis in the Root Apical Meristem of Ceratopteris pteridoides. Taiwania $1972,17,14-26$. 
102. Barlow, P.W. Meristems, metamers and modules and the development of shoot and root systems. Bot. J. Linn. Soc. 1989, 100, 255-279. [CrossRef]

103. Pi, L.; Aichinger, E.; Van Der Graaff, E.; Llavata-Peris, C.I.; Weijers, D.; Hennig, L.; Groot, E.; Laux, T. Organizer-Derived WOX5 Signal Maintains Root Columella Stem Cells through Chromatin-Mediated Repression of CDF4 Expression. Dev. Cell 2015, 33, 576-588. [CrossRef]

Publisher's Note: MDPI stays neutral with regard to jurisdictional claims in published maps and institutional affiliations.

(C) 2020 by the authors. Licensee MDPI, Basel, Switzerland. This article is an open access article distributed under the terms and conditions of the Creative Commons Attribution (CC BY) license (http://creativecommons.org/licenses/by/4.0/). 